Portland State University

PDXScholar

$11-25-1981$

\title{
The Coming of the Birdman: the Aviator's Image in Oregon, 1905-1915
}

Patrick John Harris

Portland State University

Follow this and additional works at: https://pdxscholar.library.pdx.edu/open_access_etds

Part of the United States History Commons

Let us know how access to this document benefits you.

\section{Recommended Citation}

Harris, Patrick John, "The Coming of the Birdman: the Aviator's Image in Oregon, 1905-1915" (1981). Dissertations and Theses. Paper 773.

https://doi.org/10.15760/etd.773

This Thesis is brought to you for free and open access. It has been accepted for inclusion in Dissertations and Theses by an authorized administrator of PDXScholar. Please contact us if we can make this document more accessible: pdxscholar@pdx.edu. 
THE COMING OF THE BIRDMAN :

THE AVIATOR'S IMAGE IN OREGON 1905 - 1915

\section{by}

PATRICK JOHN HARRIS

A thesis submitted in partial fullfilment of the requirements for the degree of

\section{MASTER OF ARTS}

in

HISTORY

Portland State University

(C) 1981 Patrick John Harris 
TO THE OFFICE OF GRADUATE STUDIES AND RESEARCH:

The members af the Comnittee approve the chesis of Patrick John Harris presented November 25, 1981
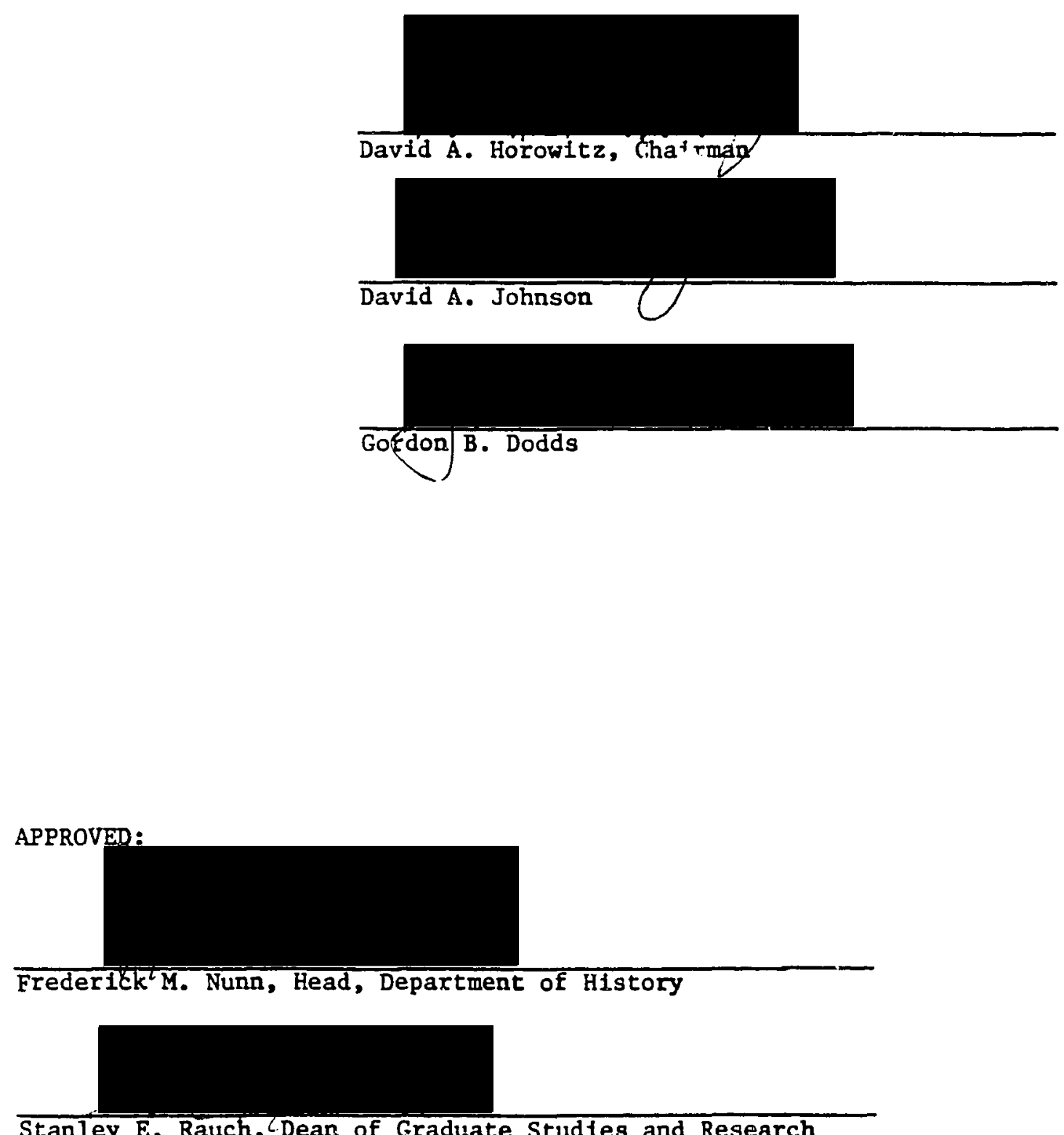

Stanley E. Rauch, C.Dean of Graduate Studies and Research 
AN ABSTRACT OF THE THESIS OF Patrick John Harris for the Master of Arts in History presented November 25, 1981.

Tit1e: The Coming of the Birdman: The Aviator's Image in Oregon 19051915.

APPROVEL D. TMEDERS OF THE THESIS COMMITIEE:

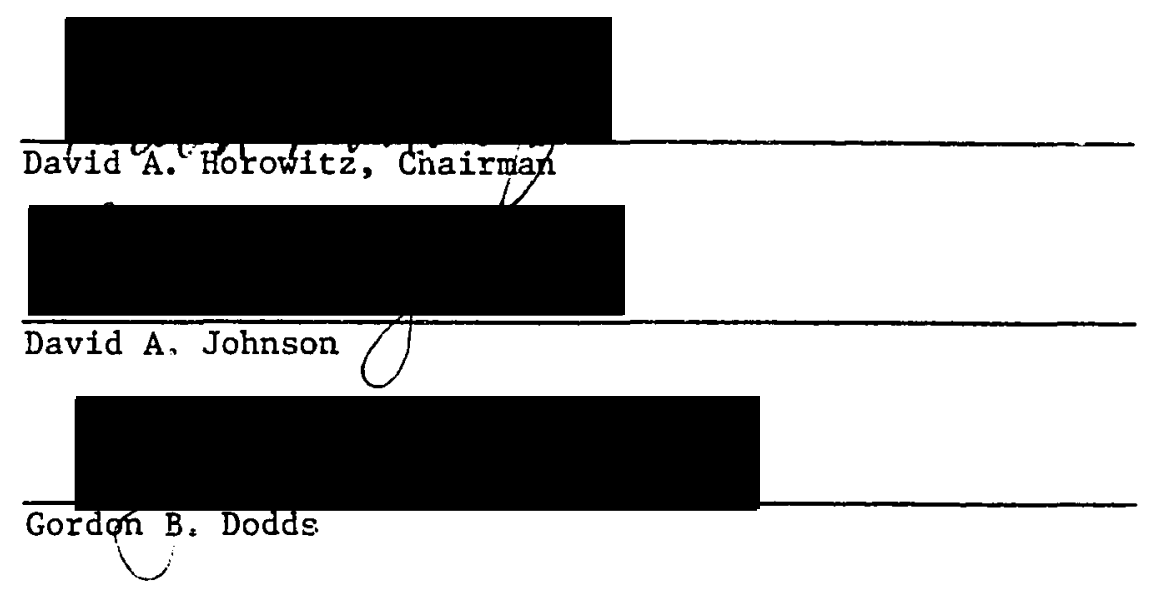

Between 1905 and 3.915 the aeroplane was tested at exhibitions and became a practical machine. Some observers, however, greeted this technological marvel with ambivalence. Skeptics felt that if the aeroplane could alter common perceptions about natural laws, it might also challenge time honored ideals and attitudes about the nature of man.

In response, newspapers and magazines fashioned the aviator's image. The aviator was daris:a yet responsible, romantic yet reasonable. Some writers and reporters believed that an aviator's selfconfidence and high woral character contributed to control in the air. By controlling the aeroplane with mastery and grace, an aviator remained master of the machine and an example of a proper way to adjust to 
rechnological changes.

Oregontans witnessed significant aviation events between 1905 and 1915. Oregon's newspapers and magazines analyzed the aviator's struggle for control at exhibitions in a manner consistent with coverage in national publications. The aviator was a birdman, a new type of man, triumphant over technology and natural forces, in part because he possessed the noblest human qualities.

After 1912 the aviator's image changed. Technological advances made spirals and loops anachronistic. The idea that an aviator was in complete control had been shatcered at exhibitions where many had been killed. These deaths did not lessen the avlator's daring appeal, but they did lead to questions abot their sanity. With the advent cf Forld War I people could no longer believe that an aviator was a responsible steward for the aeroplane. Governments and businesses took greater interest in. the aeroplane, and the aviator' $\varepsilon$ appeal as an individual in a personal struggle for control diminished.

Most bibliographical sources consulted were primary. Newspapers, magazines and manuscripts were studied exterısively because contemporary accounts focused on cultural responses to the aeroplane. Modern secondary sources often detail technological advances but pay little attention to the aviator's image. This study presents a look at the cultural changes that came with the aeroplane and asserts that the building of the aviator's inage was one response to fears about change. 


\section{ACKNOWLEDGEMENTS}

I wish to thank the staff members at the Oregon Historical Society for their interest in my subject and their ability to help me locate primary sources. My graduate advisors, David Horowitz, David Johnson, and Gordon Dodds, deserve special recognition for their willingness to let me undertake this difficult topic and to give me advice abcut content and style. I thank Lynne Blgelow for her exceptional typing of my manuscript, a task I gladiy left to her. Finally, I express my love and appreciation to my parents who always allowed me the freedom to seek creative and inaginative outlets in my iffe. 
TABLE OF CONTENTS

PAGE

ACKNOWLEDGEMENTS ........................ if

INTRODUCTION ....................... 1

Notes . . . . . . . . . . . . . . 8

CHAPTER

I THE AIRSHIP AND THE EXPOSITION . . . . . . . . . 9

Notes................ 19

II THE IDOL OF THE EXPOSITION . . . . . . . . . . 21

Notes ........................ 33

III THE BUILDING OF THE IMAGE . . . . . . . . . . . 36

Notes ................... 45

IV PROMOTING THE EXHIBITION IN OREGON . . . . . . . 47

Notes .................... 64

V LOCAL AVIATORS FLY ................ . . 67

Notes .................... 84

VI SILAS CHRISTOFFERSON AND THE TRANSITION ERA . . . . 87

Notes .............. . . 97

VII CONCLUSION: THE END OF THE EXHIBITIONS . . . . . . 99

Nctes ............................. 108

SOURCES CONSULTED

SECONDARY SOURCES . . . . . . . . . . . 110

Books ................. 110

Magazines and Journals ........... 112 
SOURCES CONSULTED

PAGE

PRIMARY SOURCES .................. 113

Books ................. 113

Magazines and Journals ............ 113

Newspapers - Articies with Authors . . . . . . 115

Newspapers ................. 116

Manuscripts ............... 117 


\section{INTRODUCTION}

Many acrounts of aviation history detail the technological evolutions in aeroplane design and pay little attention to the cultural responses to the aeroplane as an amazing technological wonder in an age of wonders. Yet between 1905 and 1915 newspapers, magazines and aeroplane publicists analyzed the ways that the aeroplane promised to alter human relationships. A common response to these changes was the building of the aviator's image as a daring and responsible figure whose struggle for control of the natural elements and crude technology was, in a sense, a struggle that all members of society had to undertake. The aviator's adjustment to technological change with mastery and grace was an answer to fears about change. This thesis studies the creation of the aviator's image in Oregon between 1905 and 1915, the period in which exhibitions were the most common way that an aeroplane appeared in public. Oregon promoters sponsored several important airship and aeroplane exhibitions, and some aviators gained a measure of initial national prominence at these spectacles. Aviation technolegy advanced rapidly as a result of tests at exhibitions, but contemporary observers paid significant attention to the aviator and his role as a steward for the new technology. These themes were covered by Oregon's newspapers and periodicals, and the pattern of coverage at exhibitions in Oregon was representative of a national pattern.

It is important, however, to know basic historic trends in aviation so that the building of the aviator's image can be studied in its proper 
context. Much thought has been devoted to flying machines for centuries, and great theoretical progress was made in the nineteenth century. John W. R. Taylor notes that Sir George Cayley developed accurate aeronautical principles while William Henson's aircraft design lacked only a feasible engine. ${ }^{1}$ Cayley, in particular, realized the similarity between the motien if bird's wings and the movement of propellers. Both of these men were deal by 1870. They worked in a period when most scientists dic not support the possibility of manned flight. During the 1890's Otto Lilienthal and Octave Chanute built and flew gliders. Chanute's interest in aviation extended to the aeroplane, and his correspondence with Orville and Nilbur Wright provides researchers with some excellent insight into the brothers' progress. Samuel Langley's scientific support of the possibility of flying inspired men such as the Wrights in their efforts to solve problems of aerial navigation. ${ }^{2}$ Langley was associated with the Smithsonian in Washington $D$. C. at the end of the nineteenth century. Cornell University was another center where aeronautical ideas were studied in the $1890^{\prime} s$. One instructor, Robert Thurston, often invited men such as Octave Chanute to speak before his class. Matthew Manly was perhaps Thurston's best known student, since he unsuccessfully attempted to fly Langley's Aerodrome in $1903 .^{3}$ Despite success or failure, these men believed by 1900 that man could fly an aeroplane, and that it was only a matter of time until one did.

Other experimenters focused attention on the airship, or dirigible balloon. Several airships had flown by 1900, and airship operators, or aeronauts, concerned themselves with dirigibility and control in the air, a question that aeroplane experimenters had discussed but had not yet faced. Colonel Charles Renard had flown an alrship in 1884 and Alberto 
Santos-Dumont amazed Parisians with tests in $1898 .^{4}$ The most influential American aeronauts after 1900 were Leo Stevens of New York and Thomas Baldwin of San Francisco. These men recognized the public appeal of their machines and brought them to the great American expositions, popular at the turn of this century. Expositions were massive spectacles that highlighted new forms of technology and symbolized the American concern for progress. St. Louis's Louisiana Purchase Exposition in 1904 attracted twenty million patrons. Portland's Lewis and Clark Centennial Exposition, held one year later, brought two million people through the gates. Stevens and Baldwin belfeved, and the crowd's enthusiasn proved them correct, that an airship was a very exciting technological development and would be a popular attraction at an exciting public spectacle. Thus the relationsip between the flying machine and the major exhibitions began.

Although Orville and Wilbur Wright made aeroplane flights in 1904 and 1905, they quit flying in 1905 because they could not obtain a patent, and they refused to fly their aeroplane for the government without one. Only in 1908 did Wilbur agree to fly in Paris and Orville in Virginia. Other experimenters in Europe made fledgling efforts to fly aeroplanes in 1906 and 1907, basically unaware that their designs lagged far behind the Wrights'. Thomas Baldwin, an American balloonist and parachute jumper, fintróduced Glenn Curtiss to aviation. Curtiss designed motorcycle engines that propelled Baldwin's airshfps at St. Louls and Portland, and were very successful. Alexander Graham Bell was so fascinated by Curtiss' success that he formed the Aerial Experiment Association with the engineer in 1907. Curtiss and others started building aeroplanes, and, oii July 4, 1908, he won the Scientific American 
Prize for the first public flight of a mile or more. Orville and Wilbur Wright met Curtiss through his association with Thomas Baldwin, and this began a strange story of suit and countersuit which lasted many years. However, Orville and Wilbur's successful flights in 1908 energized the aviation world. Their flights triggered an interest that led to the establishment of major exhibitions at Rheims in 1909 and Los Angeles in January 1910. Tnese exhibitions featured the aeroplane as the singular attraction rather than one of many others. This exhibition forum became the most common way that the aeroplane and the aviator appeared in public until World War I.

Oregunians witnessed key events in the development of the exhibition as the testing ground for the flying machine. Although Thomas Baldwin's airship had made a few good fights at St. Louis in 1904, it was not until the flights at Portland that a consistent pattern of success was established. The Lewis and Clark Exposition proved to Baldwin that he had an excellent machine. Baldwin's hired pilot, Lincoln Beachey, established his reputation at Portland, a reputation that he maintained for nine years until his death in 1915. Oregon's promoters realized that the exposition had presented the airship to huge crowds, and civic representatives planned similar exhibitions for the aeroplane. Less thán two months after the first international aviation meet ever staged in the United States at Los Angeles in January 1910, Oregonians sponsored the exhibition appearances of Charles Hamilton. Hamilton's successful flights set a standard by which local aviators could measure their progress as they sought to bufld reputations. Between 1910 and 1912 exhibitions were very popular in Oregon, as in the rest of America, and the aviator's Image building campaign in this state was 
representative of similar campaigns throughout the country.

This image building campaign is rslated to the fact that

technological improvements have often been greeted with ambivalence by

Americans who have marvelled at innovation but feared change. ${ }^{5}$ Historian

Henry F. May noted this reaction to the aeroplane when he wrote:

A fragile thing of wire and canvas, looping the loop at county fairs, it was to some of the younger generation a symbol of almost magical hopes. Tó some conservatives, man in flight was a disturbing sight; if he could do this, what natural lav could he not break? ${ }^{6}$

Writing in the early 1930's Mark Sullivan said that flying had

always seemed an impossible dream but, "if this immutability was mutable, what other dogma or authority might not be questioned; what other tradition or convention was sacrosanct?" 7 For this reason people hoped that an aviator was a special person. Americans wanted the aviator to represent the best qualities of life in the era. Society would share in the aviator's struggle for control and conquest. Arthur Gordon reflected about this struggle:

From the beginning many noile themes have been woven into the fabric of flying; man against gravity, man against distance, man against time. But the classic theme of the early years was as old as the oldest flying legend; man against death. 8

When aviators spoke to the press about their flying experiences, they sounded like extraordinary men. It was difficult for them to convey experfences not shared by most people. They were continually amazed with the fuss that surrounded their accomplishments. Aviators, scientists, engineers, and others workịng to perfect aeroplane technology accepted the notion that an aviator was courageous and nervy, but they realized that he was helpless in an unsafe machine. Nevertheless, the romantic image of the aviator remained. The aviator, 
flying in the alr with the birds, was a romantic figure; his perspective made him a birdman. As it appeared that a bird knew where it wanted to go, so was it hoped that a man with high moral character wiuld be aule to demonstrate the peaceful applications of the newest and best form of technology.

After 1912 aviators were criticized for taking unnecessary risks. Most observers failed to see the connection between stunting at exhibitions and practical applications. Many aviators, in the absence of peaceful applications, encouraged governments to study the aeroplane as a war machine. The grandiose idealism which surrounded the aviator's ability to shape a positive direction for the aeroplane was eroded. World War I led to improvements in aeroplane technology, and it removed the aura of innocence and frivolity from aviation which had prevailed during the exhibitions. While exhibitions had been used as a testing ground for war games, it was difficult to appreciate the seriousness of tests which involved tossing oranges and flour sacks at targets on the ground. The wartime aviator retained a daring and romantic image, but it was hard for people to believe that they had nothing to fear from him. Perhaps the overwhelming puilte reception that Charles Lindberg received in 1927 is better understood in the context of the early hopes and expectations about the future of aviation. Americans continued to hope that a peaceful, solitary, and daring figure represented aviation rather than the highly technical machine. Iindberg crossed the Atlantic and restored glamour and romance to aviation in a venture that was a throwback to the days when the aviator's image had been fashioned. Lindberg, however, never appreciated the attention. To Americans, according to John William Ward, Lindberg's accomplishment gave, "a 
g1impse of an ideal when it seemed that it had been 1ost." 9 One American ideal has always been the symbol of the self-reliant man. Lindberg's flight certainly was a triumph for modern technology, but most Americans did not wish to honor the machine. The aviator was considered a pioneer, and Ward argues that this attitude indicated a public compromise between the role of the man and the machine. Ward wrote:

By calling Lindberg a pioneer, the people could read into American History the necessity of turning back to the frontier past. Yet the people could also read American History in terms of progress into the industrial future. ${ }^{10}$

Al1 of these themes were present at exhibitions in Oregon between 1905 and 1915. Thus, Oregon's newspapers and magazines contributed to the image building campaigns occurring also at the national level. Every aviator began his career at a local event, and, if successful, he became a national figure in avtation. Oregon's newspapers and magazines built the initial reputations of Lincoln Beachey, Eugene Ely, and Silas Christofferson. Because these men went on to become nationally famous aviators it is possible to study their national careers and to assert that the pattern of image building in Oregon was consistent with patterns found in national publications. A study of Oregon's newspapers and magazines during this ten year period also indicates a greater contemporary interest in the cultural implications of the aeroplane and, consequently, the character of the aviator. This local concern was also a national concern, and the creation of the aviator's image in Oregon is representative of newspaper and magazine coverage of the era. 
NOTES

INTRODUCTION

1 John W. R. Taylor and Kenneth Munson, History of Aviation (New York: Crown Publishers, 1972), p. 39.

2

Tom D. Crouch, A Dream of Wings: Americans and the Airplane, 1885-1905 (New York: W. W. Norton, 1981), p. 228 .

3 Crouch, p. 76.

${ }^{4}$ Claude Graham-White, Flying: An Epitome and a Forecast (London Chat to and Windus, 1931), pp. 27-29.

5 Gilman Ostrander, American Civilization in the First Machine Age, 1890-1940 (New York: Harper and Row, 1970), pp. 151, 237-273; John F. Kasson, Civilizing the Machine: Technology, and Republican Values In America, 1776-1300 (New York: Grossman, 1976), pp. 55, 196, 183-234.

6

Henry F. May, The End of American Innocence: A Study of the First Years of Our Time, 1912-1917 (Chicago: Quadrangle Books, 1959; rpt. New York: Charles A. Knoph, 1954), p. 335.

7 Mark Sullivan, Our Times: 1900-1925, The War Begins, Volume IV (1932; rpt. New York: Charies Scribner's Sons, 1972), p/ 215.

8 Arthur Gordon, The American Heritage History of Flight (n.p.: American Heritage, 1962), p. 118.

9 John W. Ward, "The Meaning of Lindberg's Flight," American Quarterly, 10 (1958), p. 6.

10

Ward, p. 13. 


\section{CHAPTER I}

THE AIRSHIP AND THE EXPOSITION

The first 1mportant public exhibitions of flying machines in the United States occurred in the Louisiana Purchase Exhfbition held at St. Louis, Missouri in 1904 and the Lewis and Clark Centennial Exposition at Portland, Oregon in 1905. The whole point of the aeronautical contests was to see if the problem of aerial navigation could be solved. The expositions provided opportunities for aeronauts to gather in one place where they and their machines could be judged by the press and public. These expositions were grand spectacles that attracted millions of people by featuring the latest forms of technology. The crowds were amazed to see a person fly any kind of machine, and although the star flying machines were dirigible balloons, or airships, even owners of hydrogen gas balloons received attention.

Dirigible balloons were designed to give an aeronaut control of the vehicle. Once the hydrogen provided lift from the ground, the aeronaut activated a motor and propeller and walked along the undercarriage using a rudder and his weight to steer the craft. The aeronaut was in control as long as a strong wind was not encountered and the equipment operated as it was designed.

Reporters and writers at St. Louls had some of the earliest opportunitles to witness the flight of an airship, and they helped build the image of the daring, courageous, and responstble aeronaut. While the 
St. Louis Exposition did not provide the first occasion in which aeronautical contests were scheduled as part of an exposition it did offer the first successful airship filights at a major public event in the United States. Promoters at St. Louls expected ninety aeronauts to compete in contests which offered $\$ 100,000$ to the person who travelled a course ten to fifteen miles at the highest average speed. Aeronauts Dr. August Greth, Charles Stanley, Octave Chanute, Leo Stevens, George Tomlinson, Samuel Langley, Hiram Maxim, and Thor as Baldwin deposited $\$ 250$ as an entrance fee with the aeronautics department, and newspaper reports hinted that the aerial contests promised "more in the spectacular line than anything yet produced by the Exposition. ${ }^{\bar{I}-1}$ Americans with an interest in aerial navigation watched events closely at St. Louis because the world's best aeronauts were expected participants. However, by the last day of the Exposition only a few had actually appeared in the city. Aviators Orville and Wilbur Wright seriously considered bringing their aeroplanes, but Wilbur, in particular, did not believe that the rules were "fair to the competitors."I-2 He also had not been impressed by the claims made by some of these men. In a letter to Octave Chanute he wrote:

The newspapers are full of accounts of flying machines which have been building in cellars, garrets, stables, and other secret places, each one of which will undoubtedly carry off the hundred thousand dollars at St. Louis. They alI have the problem 'completely solved' but usually there is some insignificant detail yet to be decided, such as whether to use stean, electricity, or a water motor to drive $1 . .1-3$

This skepticlsm was justified. George Tomlinson brought considerable attention to the contests when he attempted to fly a hot air balloon from St. Louis to the Washington Monument, but Tomlinson was forced to 
land in Illinois. His flight was the only significant one until late October.

As Wright had noted, the competition's distance and maneuverability rules were partially responsible for the lack of aeronaut participants. Dirigible balloons in 1904 could not meet the rigid requirements. Perhaps Wilbur and Orville Wright could have captured the top prize, but chey remained in Dayion fiying in relative seclusion.

Captain Thomas Scott Baldwin, an aeronaut from San Francisco, was one man thankful that the Wrights stayed home. Born in Missouri in 1864, Baldwin began flying balloons in the $1880^{\prime} \mathrm{s}$. He developed a successful parachute with "an eye to thrilling the crowds and making money". "-4 He adapted the alrship design of Alberto Santos-Dumont and conducted test flights in San Francisco. In the spring of 1904 he secured a motorcycle engine, designed by Glenn Curtiss, for his California Arrow. His flights, during the summer of 1904, marked the first time that an American had piloted a dirigible balloon in a circular partern and returned it to its starting point. ${ }^{I-5}$ on the success of these flights, he was invited to St. Louls, arriving with his airship in October. Baldwin hired Roy Knabenshue to pilot his craft, and the team surprised all when Knabenshue flew fi from St. Louis to Cahokia, Illinois on October 25th. People in St. Louis were astounded by the airship above their heads. As the New York Times reported, "clerks deserted their desks, street cars were stopped, and all business suspended until the machine passed."I-6 Knabenshue covered three and one half miles in twenty eight minutes a few days later and was greeted by a jubilant mob that carried him on their shoulders. He was honored for his control of the machine a 
control that the aeronaut emphasized in public statements. Yet he also told the crowd that flying was great fun, and he minimized the danger of the experiments:

There was not a moment when I did not have complete control of the airship. The sensation was most pleasant. I did not have time to think of danger. An operator of the Baldwin Arrow need only to have an average amount of nerve, a 11ttle experience as an aeronaut, and he can make a successful flight. I-7

St. Louis promoters were pleased that they had delivered on part of their promised airship flights. When the New York Times declared that Knabenshue's flights were the best ever made in the United States, it seemed that his celebrity status was assured. ${ }^{I-8}$ Knabenshue, meanwhile, blended reason and romance in descriptions:

When a fellow reaches a height where the cheers of the crowd are no longer heard and all above and below and around him are the vastness and silence of the infinite he feels as he never has felt or could feel on land or sea. I-9

Knabenshue's own descriptions of his aerial accomplishments revealed an awareness that a new man must evolve to meet the challenges of twentieth century technology. While he insisted that he was an ordinary person, his reflective sti.tements suggested that no ordinary human being could understand his experiences. His sentiments portrayed the aeronaut as the symbol of the human capacity to adjust to technology with mastery and grace. The aeronaut was the "new man" who could meet the challenges created by the new technology by seeing them from a higher perspective. Knabenshue, in this respect, was a representative aeronaut in 1904 who had demonstrated control of the highest forw if technology yet unveiled. Newspaper accounts pictured him as cool, calm, daring, and self-confident; a man whose personality coniributed to his success as an aeronaut. 
Baldwin and Knabenshue earned an estimated $\$ 25,000$ at St. Louis. I-10 By mid-November Baldwin packed his airship for the return to California. Businessmen from Toledo, Ohio, offered knabenshue a contract to build and f1y an airship in their city, but the aeronaut felt loyalty to Baldwin and continued the partnership. As the two men left St. Louis, Baldwin was hailed as the only inventor of aerial craft "that has succeeded in accomplishing anything of importance at the Exposition." ${ }^{I-11}$ Business leaders from Ohio were not the only civic representatives to express an interest in an airshin. Others included Theodore Hardee, assistant to the president of the Lewis and Clark Centennial Exposition to be held at Portland in 1905. Hardee raalized that Baldwin's airship would be an excellent attraction for the city because the aeronaut's reputation assured greater publicity for the exposition. Portland was a long way from America's pepulation centers in 1905, and promoters felt that Baldwin's airship might encourage more people to travel to the Northwest. Portland officials also believed that an airship show would underline the theme of their exposition, that an industrious and progressive people had settled the oregon Territory and prepared it as a gateway for American expansion into the orient. ${ }^{\mathbf{I}-12}$

The clty of Portland and state of Oregon had raised nearly one million dollars by 1904 for the event. The Exposition also recelved two million dollars from Congress. As Lewis and Clark explored the land for President Jefferson and exhibited its potential to $h \pm m$, so, in 1905, were Oregonians planning to show the rest of the nation how the possibilities had been fulfilled; indeed how the region was ready to take 1 ts place at the end of one frontier and at the beginning of another. What better way to publicize this progress than by focusing attention on an extraordinary 
event? The appearance of an airship at the exposition would be dramatic proof that Oregonians were aware of the world's newest wonder and foremost symbol of the new century's potential.

Even though Baldwin and Knabenshue had made a good impression on Theotore Hardee at St. Louis, Portland officials were not ready to evaluate the exact nature of the aerial contests until January 1905. John Wakefield, the director of the department of concessions at St. Louis, was appointed to the same position in Portland. He arrived in January as "the best posted exposition show department chief in the United States, beyond a doubt. ${ }^{\mathrm{I}-13}$ He immediately began to answer queries from aeronauts who had written Portland about the proposed aerial contersts.

George Tomlinson and Leo Stevens, captive balloon operators at Sť. Louis, hoped for similar contracts at Portland and wrote to offer their services. I-14 Portland officials, however, showed little more than passing interest in the two men because they were after Baldwin. Wakefield informed the men not to expect contract decisions quickly. ${ }^{\mathrm{I}-15}$ Baldwin and Knabenshue, meanwhile, continued to impress observers. In late January Knabenshue flew the Calffornla Arrow forty five minutes and circled within a radius of one mile. Having served in St. Louis, Wakefield was familiar with the California A.rrow, and he apparently felt that it would be foolish to pass up an opportunity to bring it to Portland.

The first communications related to Baldwin came in February when J. H. Car -enter, Vice President of the Baldwin Airship Company, wrote to Portland to inquire about exposition plans for airships. ${ }^{\mathrm{I}-16}$ Carpenter 
and other eastern investors looked to Portland as an excellent forum to further test their airship. Wakefield gave Carpenter a complete explanation of the tentative plans. He hoped that Portland could secure a number of afrships managed under the auspices of one aeronautical concession director who contracted with the aeronauts. The aeronauts could charge admission to an enclosed area "within and from which the airships are stabled, prepared for flights and returns, also including the operatinn of a captive airship."I-17

Baldwin wrote Wakefleld on February 18 th and expressed his desire to compete in Portland if the city were better prepared to handle the contest than St. Louis had been. He expected a thoroughly professional operation which insured an adequate hydrogen gas supply for his airship. Baldwin recognized the promotional interests of exposition officials, and he assured them that, "I Iive out here on the coast and am anxious to see the Lewis and Clark Exhibftion be a little world beater in its own way." $\mathrm{I}-18$

Stevens and Tomlinson were frustrated by the apparent indecision surrounding the granting of the concession award. They warned the exposition that preparations for competition were not possible if a decision was continually delayed. ${ }^{\mathrm{I}-19}$ Stevens, in particular, was Irritated by a lack of recornition of his important role in aeronautics. He had been the first American to fly a dirigible balloon, but his preeminence in the ficld had long since disappeared. The two men did not know that Wakefield had already offered the concessions contract to Major T. S. Clarkson while in St. Louis the past December. Clarkson helped suggest Ideas for the Portland contests, and he convinced Wakefield that 
one aeronautical director should be hired as a complete supervisor. Clarkson ano Baldwin were good friends, and they had discussed the possibility of joining their interests at Portland. Wakefield thus had a possible motive for delaying an announcement of the concession award until Clarkson visited Portland in March. Wakefield informed him that a final decision would not be rendered until he arrived and had an "ample opportunity to consider the subject thoroughly and look over the grounds."I-20 In a letter to Baldwin Wakefield stated that clarkson was "a very capable businessman . . . and I know him to be a thoroughly responsible and capable manager."I-21 Baldwin responded that Clarkson would be a wise choice in line with his demand for professional operations. I-22 Wakefield then offered to tie the men together, suggesting to the aeronaut a "jointure of your interests and his interests in the proposed enterprise."I-23

Clarkson arrived in Portland on March 5 th and formally accepted the title as director of aeronautical concessions. The decision was announced to the public on March 23rd, stating that the contract had been signed with the Aerial Navigation Company of Portland. This company, formed with Clarisson as the major interest, probably included investors from the Baldwin Airship Company and perhaps Thomas Baldwin. The Lewis and Clark Journal reported that Baldwin was bringing his California Arrow to the Exposition. ${ }^{\mathrm{I}-24}$ Newspaper reports created expectations that many tamous aeronauts were coming to Portland, but negotiations had not encouraged aeronauts other than Baldwin. Baldwin was the premier designer of afrships in the country and negotiations seemed to zeflect that reality. Sti11, a newspaper article on March 26 th boasted: 
Every known aeronaut and inventor in the United States is included in the invitation list which has already been prepared. The Inducements offered are good. The expenses of operating the machines will be borne here. A site will shortly be selected for a big gas tank from which the balloons may be filled free of charge to all competitors... . of course there will be some contrivances that will not $f l y$, or that could not be raised without a derrick, for that matter. But several live airships will atone for these shortcomings on the part of inventors who are suffering from delusions. $1-25$

As late as April the form which the aeronautical contests would take was still a matter for discussion. Wakefield corresponded with Walter Stevens, the secretary of the St. Louls Exposition, and asked to use Stevens' regulations as a guide for developing Portland's program. ${ }^{-26}$ Theodore Hardee requested coples of release forms issued to aeronauts that absolved the exposition from liabiity in case of accident. ${ }^{I-27}$

A pamphlet Rules and Regulations Governing the Aeronautic Competition was released in hay. The rules adopted were similar to those at St. Louis though competition requirements were lowered. A $\$ 10,000$ prize was offered to the aeronaut who travelled a ten mile L-shaped course at least twice at an average speed of 15 miles per hour. A $\$ 1,000$ prize was offered to the aeronaut who took off from exposition grounds and landed closest to the Mormon Tabernacle in Sait Lake City. Finally, a $\$ 500$ prize would go to the aeronaut who flew the furthest distance in any direction if he remained airborne for ten hours. Aeronauts were required to depostt a $\$ 100$ entrance fee, and, while the amount was less than what St. Louls had asked, the prize money was considerably less as we11. All competing aeronauts were asked to provide evidence that they had flown at least a mile, and all competitive flights were to ho fuiged by a three member aeronautical jury. I-28

In late April Portland faced an unexpected problem. Knabenshue 
left Baldwin to return to Ohio to build his own airship. The Oregonian reported that the aeronaut still hoped to come to Portland on his own. ${ }^{\text {I-29 }}$ This set up the possibility of a contest between Baldwin and Knabenshue, with Baldwin having an untested pilot who might be easily defeated in a conpetition with Knabenshue. Baldwin chose Lincoln Beachey, an eighteen year old pilot in his airship company, to fly for him at Portland. This gave Beachey his first chance for national recognition.

After Baldwin hired Beachey, exposition president Goode wrote to Baldwin detailing his contract:

You agree to bring your airship to the Exposition, exhibit same, do all in your power to foster aerial navigation interests at the Exposition, make at least twenty flights, these flights to be from the aeronautic concourse, to and around Fortland Heights and return to the Exposition grounds or an equal distance or circuit in any other direction. $1-30$

The requirement for twenty ilights was an amazing stipulation. If Baldwin and Beachey were able to fulfill the contract they would do more for aerial navigation than had previously been ascomplished. Baldwin was promised $\$ 250$ for each successful round trip and $\$ 125$ for a one-way flight. He also had the right to compete for larger prizes if airship contests occurred. After Major Clarkson informed Goode that Baldwin understood that his airship had to remain airborne for thirty minutes to be eligible for the money, Baldwin accepted the contract as "very liberal," and it was. ${ }^{I-31}$

Portland's Lewis and Clark Centennial Exposition had signed a contract with the most renowned airship builder in the United States. The exposition promised to give aerial enthusiasts another opportunity to monitor airship progress, and it also set the stage for Baldwin and Beachey in their search for personal honors as designers and aeronauts. 
NOTES

CHAP'IER I

1 "Ninety Aeronauts to Battle in Air," New York Times, 4 Sept. 1904., p. 9. col. 4.

2 Fred C. Kelly, ed., Miracle at Ritty Hawk: The Letters of Wilbur and Orville Wright (New York: Ferrar, Straus, \& Young, 1951), p. 132.

3 Harry Combs with Martin Cardin, K1ll Devil Hill: Discovering the Secret of the Wright Brothers (Boston: Houghton Mifflin, 1979), p. 156.

4 Gary F. Kurutz, "'Navigating the Upper Strata' and the Quest for Dirigibility," California History: The Magazine of the California Historical Soctety, 58, (79-80), 343.

5 Kurutz, p. 344.

6 "Airship Flies Ten Miles," New York Times, 26 0ct. 1904, p. 1, $\operatorname{col} .4$.

7 "Baldwin's Alrship Makes a Successful Flight," New York Times, 1 Nov. 1904, p. 9, col. 1 .

8 "How Baldwin's California Arrow Navigates the Air," New York Times, 6 Nov. 1904, part. 3, p. 6, col. 1-7.

9 New York Times, 6 Nov. 1904.

10 Lloyd Morris and Kendall Smith, Ceiling Unlimited: The Story of Aviation from Kitty Hawk to Supersonics (New York: MacMillan, 1953), p. 81 . col. 5 .

11 "Baldwin Packs Airship," New York Times, 11 Nov. 1904, p. 2,

12 "Salutatory," Lewis and Clark Journal, 1, No. 1 (1904), p. 10.

13 "Good Shows Coming," Lewls and Clark Journal, 2, No. 3 (1904), p. 9.

14 George Tomlinson, Letter tc John Wakefield, 10 0ct. 1904, Lewis and Clark Centennial Exposition Manuscripts, Oregon Historical Society Library, Portland, Oregon, Mss. 1609, Box 5, sec. 287; Leo Stevens, Letter to President Goode, 22 Nov. 1904, Mss. 1609, Box 5, sec. 287. 
15 John Wakefield, Letter to Leo Stevens, $14 \mathrm{Jan} .1905$, and John Wakefield, Letter to George Tomlinson, 18 Jan. 1905, Mss. 1609, Box 5, sec. 287.

16 J. H. Carpenter, Letter to Managers, Lewis and Clark Exposition, 8 Feb. 1905, Mss. 1609, Box 9, folder A-B.

17 John Wakefield, Letter to Baldwin Airship Company, 15 Feb. 1905, Mss. 1609, Box 9, folder A-B.

18

Thomas Baldwin, Letter to John Wakefield, 18 Feb. 1905, Mss. 1609, Box 9, folder A-B.

19 Leo Stevens, Letter to John Wakefield, 20 Feb. 1905, Mss. 1609, Box 5, sec. 287.

20 John Wakefield, Letter to Thomas Baldwin, 21 Feb. 1905, Mss. 1609, Box 9, folder A-B.

21 Wakefield to Baldwin, 21 Feb. 1905.

22 Thomas Baldwin, Letter to John Wakefield, 23 Feb. 1905, Mss. 1609, Box 9, folder A-B.

23 wakefield to Baldwin, 21 Feb. 1905.

24 "Airships Coming," Lewis and Clark Journal, 3, No. 3 (1905), p. 5.

25 "To Conquer Air," The Oregonian, 26 Mar. 1905, p. 5, col. 2.

26 John Wakefield, Letter to Theodore Hardee, 29 Apr. 1905, Mss. 16 ' 9 , Box 15, Lct 40, No. 354.

27 Theodore Hardee, Letter to Nalter B. Stevens, Secretary of the St. Louis World's Fair, 3 May 1905, Mss. 1609, Box 15, Lor 40, No. 354.

28 Lewis and Clark Centennial Exposition, Rules and Regulations Governing the Aeronautic Competition (Portland: LCCE, 1905), Mss. 1609, Box 15, Lot 40, No. 354.

29 "Ship to Fly at Fair," The Oregonian, 1 May 1905, p. 3, col. 5. 30 H. W. Goode, Letter to Thomas Baldwin, 19 May 1905, Mss. 1609, Box 15, Lot 40 , No. 354.

31 Thomas Baldwin, Letter to Theodore Hardee, 23 May 1905, Mss. 1609, Box 15, Lot 40, No. 354. 
CHAPTER II

THE IDOL OF THE EXPOSITION

Lincoln Beachey, in his flights at Portland, built an image that became a model for aeronauts and aviators that followed him. The Lewis and Clark Centennial Exposition proved even more 1mportant to Thomas Baldwin than the Louisiana Purchase Exposition because his machine performed with greater consistency for a longer period of time. Honors were Iiberally extended to Baldwin and Beachey, and Baldwin's choice of Beachey proved wise because the flights brought fame to the aeronauts and the exposition. II-1

Beachey was born in 1887 in San Francisco and began work as a clean-up boy at the Stanley Aerial Navigation Company when he was thirteen. He made his first balloon flight at sixteen, sailing across San Francisco Bay. Thomas Baldwin often saw Beachey and, recognizing the bcy's aerial talents, approached Beachey with an offer to work for him at a better salary. Beachey's first airship flight came in April 1905, and he seemed the natural choice to replace Knabenshue as Baldwin's aeronaut at Portland.

Baldwin had numerous problems during the spring of 1905. Not only had Krabenshue left his employment, but he also faced a suit by Professor John Montgomery for patent infiringement in a dispute over the design of the California Arrow. When Baldwin and Beachey arrived in Portland sometime in June 1905, they brought the airship, Angelus, 
electing to leave the California Arrow behind. The Lewis and Clark

Journal described the Angelus in the following way:

- . Its balloon having a capacity of 16,000 cubic feet, capable of carrying the machine and itself, weighs about 400 pounds, the major portion of this being in the framework and engine, 210 pounds in all. The engine is what the inventor calls perfection itself, even though it does occasionally refuse to work, as high strung engines or men, will sometimes. it is seven and one half horsepower, two cycle, gasoline motor, capable of revolving the five foot propeller blades at 250 revolutions to the minute. The framework is triangular, and the aeronaut stands on the side of the triangle and manipulates the decent or ascent of the machine by moving forward or backward. II-2

As Beachey and Baldwin made preparations for airship flights, Theodore Hardee asked that he be notified well in advance of their first one sis that he could inform the press and insure a wider coverage of the event. II-3 Baldwin's airship was not the only one in Portland because George Tomlinson had decided to make the trip even though he had not been selected as the concessions director. The Oregonian reported on July 14th that Tomlinson was in St. Louis heading to Portland. The paper also revealed that Tomlinson had spoken with Roy Knabenshue in Dayton and planned an aerial contest with him after the Portland Exposition. II-4 knabenshue dropped his flans to visit Portland, opting to fly over New York instead.

Tomlinson reached Portland on July 18th, the day of Beachey's first flight. The Angelus rose easily into the air but its propeliers failed to operate, and the airship was driven four miles to the south by the wind. Beachey finally landed on the east side of the Willamette River near Caks Park. It was not a very good beginning, but the Oregon Journal remarked that many people were still impressed because they had never 
seen anything like it. ${ }^{\text {II-5 }}$ The Oregonian, however, expressed the prevailing sentiments:

Man tried again yesterday to conquer air. It was the same old story of partial defeat. He must try yet again before he can slip the metaphorical harness upon the atmosphere and make it serve him as the giants Steam and Electricity have been brought to serve. II-6

The airship was towed back to the Exposition grounds, and attempts were made to fix the propeller. At the end of July Hardee requested the Angelus fly every Tuesday and Friday afternoon, and Clarkson told him that every effort was being expended by Baldwin to allow for a regular schedule. ${ }^{\mathrm{II}-7}$ In Beachey's second flight, the propeller failed again. Spectators on the ground, unaware that Beachey had problems, cheered the aeronaut even as he was struggling to control the airship. Reporters covering the flight portrayed Beachey as a daring individual willing to risk life and limb in his personal contest with the atmosphere. Even they falled to recognize, however, that Beachey's greatest adversary was the airship, not the wind. II-8 Beachey landed the Angelus without incident, but he and Baldwin realized that it was not a good airship and started to build a larger one. Baldwin's reputation was suffering a bit, and the men must have felt a sense of urgency in the new construction. Other aeronauts were beginning to take the headlines from Baldwin. Roy Knabenshue, Leo Stevens, and Alberto Santos-Dumont flew their respective airships at different places that summer, and all of them had performed quite well. II-9

Beachey's final test in the Angelus came on Airgist gth and it was more successful than the first two. The Oregon Journal noted that the 
winds failed "in their battle with aerial navigation", but this observation was only partially true. Beachey did get the afrship to 1200 feet, yet the reporter admitted, "The craft was making slow progress, of course, but was able to defy the current . . ."II-10

A new airship titled City of Portland was ready for testing by August 20th. It was larger than the Angelus, and it had a more efficient propeller powered by a seven horsepower engine designed by Glenn Curtiss. II-II Beachey circled the entire fairgrounds and returned to within sixty feet of his starting point. A crowd of 5000 people watched as "perhaps the most daring aeronaut in America" piloted the craft. Baldwin was satisfied and indirestly issued a challenge to other aeronauts:

I know of no demonstration heretofore that is more encouraging than that this afternoon. I am willing right now to back the City of Portland against any airship and I do not exclude the California Arrow the record of which has been before the public several years.

Baldwin knew that his lead in airship construction was shrinking. Airships were relatively easy to build and, as Roy Knabenshue had remarked at St. Louis, not difficult to fly if the aeronaut had nerve. Indeed, Knabenshue was flying his own airship in New York City at the same time, and competition was very close between the men. The New York Times said that Knabenshue was

- . slender of stature but with plenty of sinew and muscle. His type is dari. The clean-cut, handsome, smooth-shaven face shows those deep lines around the eyes and mouth that so of ten appear as signs of strong will and intense brain power. II-13

The Times reported that people were siunned by the flights:

He had not heen up five. inutes when it seemed to those on the tower of the Times building that none but invalids and cradled babes could have remained indoors in the Borough of Manhattan. 
Every house, as far as the eye could reach, was filled with men, women, and children, all of them gazing upward in rapt contemplation of the same object - the traveler in the skies.II-14

As Beachey started making successful flights, he too was hailed by Oregon's newspapers. The Oregon Journal observed that Beachey circled three times on August 22nd and then flew to the Columbia River and back. The paper insisted that the new airship was the "first absolutely practical dirigible balloon."II-15 Major Clarkson told Hardee that Portlanders had seen the best performance by any alrship ever recorded because Beachey had remained airborne for over forty minutes and maintained perfect contro1. II-16

Fair promoters realized that the airship was a wonderful attraction, and they promised numerous spectacles. Exposition secretary Henry Reed announced in late August that Tomlinson wanted to zace Beachey. He asked the press to publicize the event because 1t promised to be the first time that two airships raced from the same starting point with a requirement to return. II-17 Beachey tuned for the race by flying forty minutes on August 30th. The Oregon Journal headlined its story with "This Flight Beats the World."II-18 The two airsh1ps were compared in the Lewis and Clark Journal, and although Tomlinson's Gelatin was similar to the Clty of Portland, its bag had a more elliptical shape. I. $1-19$

Unfortunately, the Gelatin broke down the day of the race, preventing a competition. Beachey, hearing spectators grumble that the aeronauts were afraid of the wind, decided to fly the City of Portland anyway. It was a very windy day, and the airship's propeller falled to operate. The aeronaut's hasty decision almost cost him his life. 
Beachey began to "think of home and mother" and crashed, narrowly averting serious injury, ripping the gas bag of the airship. Although his effort received praise, nothing could assuage his damaged pride. II-20 With the City of Portland out of service, Tomlinson attempted his first flight on Spetember 4th. The Gelatin worked well for twenty minutes, but the propeller then stopped working, and Tomlinson was helpless as the wind blew his craft into Poitland Helghts. Clarkson and Beachey hopped in a car to search for their friend and located him after a short time, unhurt and the airship undamaged. The Oregon Journal did not blame Tomlinson for the accident, noting that his "tacking was without fault unil the accident to the machinery." II-21

Tomlinson apparently dectded to quit flying in Portland and agreed to transfer the gas bag of the Gelatin to the undercarriage of the City of Portland. On September $6 \mathrm{th}$, Beachey returned to the air with the airship affectionately dubbed Mongrel. He made successful flight after successful flight as the month progressed. By mid-September Portland's newspapers were clamoring for interviews with the aeronaut who had amazed the fairgoers with his skilled control of the airship. Beachey spoke confidently about the future of aertal navigation as mankind learned about natural laws which, if obeyed, made flying possible. In this way he simplified the art of flying as well as ninimized his personal achievements. One reporter, however, was not wiling to accept this approach and wrote: "Few Portlanders realize fully the remarkable aerial navigation achievements that have taken place at the Lewis and Clark Exposition this summer."II-22 By writing the article in this fashion the reporter made more out of Beachey's accomplishments than the aeronaut wanted him to do. The Oregonian informed 1ts readers that 
Beachey's flights had implications beyond local curlosity because they affected the future of aviation. Although the technology was yet unimpressive, it was important to recognize that Beachey was building self-confidence with each successful flight. The Oregonian writer remarked:

Beachey is the idol of the Lewis and Clark Exposition, if such a term might be applied, and attentions and honors have been showered on him, but in spite of all this, his head is not turned in the least. He cares absolutely nothing about notoriety but has devoted his life to the great task of the conquering of the elements. II-23

In this way, newspapers fashioned the image of the aeronaut, and later the aviator. Reporters portrayed the pilots as unselfish men seeking the long term goal of victory over the air, yet remaining unmoved by acclaim. Beachey became one of the first models for the development of this image, and his personal stataments were of ten used to prove that he combined a daring nerve with a rare understanding of technology. People admired such a person because the aeronaut concrolled an aspect of new technology, and he gave them confidence that everything would work out for the best. Aeronauts and aviators who came after Beachey had to live up to this earlier image. They were considered to be intuitive geniuses who knew how to react to danger because they lived with it every time they flew an airship. The aeronaut was in a flight against the wind, and it was a struggle to the death. If the aeronaut failed in the personal struggle, others could analyze mistales and apply the lessons to future flights. This popular image also assumed that an aeronaut was bo:n tc be an aeronaut just as a poet was born to be a poet. As The Oregunian rernrted, "Those who have closely followed the career of Beachey say he was born to be an aeronaut, 
the same as Longfellow was born to be a poet. It is in him and will remain with him throughout."II-24 Both professions combined a balance of skill and intuition, and the aeronaut's romantic image was no less important than his scientific one.

The image created by newspapers and magazines aid not accurately describe the actual personalities of the aeronauts. Most of them were courageous, but they also realized their vulnerability in a stiff wind. The best aeronauts realized that it was ludicrous to claim total control of an airship so little understood, but they wanted to believe it. As Beachey told one reporter:

When I go up in an airship I hardly realize that I am above the ground, so natural does it seem. The air and the ground are both alike to me... Even when I first went up in a balloon I was not nervous. I really liked the sensation. Some people intrinsically like certain things and I guess that is the way with me and the airship. II-25

Beachey's message was that flying was a natural experience; very pleasant and hardly dangerous at all. Newspapers and magazines insisted that aviation technology was Improving, and courageous aeronauts were willing to battle natural forces in crude machines until better ones were designed. The airship and aeroplane, however, were novelties, and nothing more, until a pilot could demonstrate his or her total control. Beachey believed that flying was a science, and he recognized that he had to learn and follow the natural laws of tine air. He reduced the struggle between the aeronaut and the elements by pointing to these laws. "I do not anticipate any accidents as really when a person knows his business the danger is reduced to a minimum," he said, "The chances against you are so insignificant that they are hardly worth mentioning." II-26 
Beachey circled the Oregon Journal Building with the Mongrel on September 15th, and the paper proclaimed that flying in the air would soon be commonplace. The editorial emphasized the perspective of the recent past and the promise of the future by saying that the "problem of aerial navigation will be practically solved."II-27 Baldwin allowed photographers close to the airship during its ascent and descent, and other people surged around Beachey as the cameras captured their enthusiasm. Some of the excitement was too much for Beachey, and he struggled to free himself. He was surrounded by women, and the Oregon Journal interpreted his reluctance as a sign of modesty rather than irritation. ${ }^{\text {II-28 }}$ Beachey, however, never liked crowds and expressed his anger in a piece that he wrote for the Journal:

This heroic stuff about nerve and pluck never made a hit with me. I make my living out of aeronautics - that's my business. And I don't feel that I'm taking any more chances than the businessman who goes home to dinner in a cab or makes a side trip to Salem in a railroad train. Honestly, I don't. II-29

Although few people believed such statements, Beachey still tried to shift their attention from the danger and mystique of flying to its relative safety. Beachey trusted Baldwin and did not feel that his mentor would risk his life easily. At the same time, Beachey confronted a dilemma. He knew that flying was not ordinary, but he wanted to convey his confidence in the airship, ard he hoped people would pratse it rather than him. He patientiy explained the aeronaut's role in the operation of an airship and recognized that anyone who wanted to fly like him had to be able to contain excessive emotion. "I know people," he wrote,

who have an inclination to leap to terra firma after they get about 200 feet in the air. That won't do for an airship. If a 
machine gets caught by an upper current the chances are it will go 1800 feet in the air. In that case you have to keep your nerve and go on until you find a more agreeable current - one that will bring you back. II-30

Even though Beachey did not overemphasize the personal qualities of the aeronaut he did leave an impression that nerve, and pluck, and presence of mind were as important to a successful flight as a good machine. Thus, trying to avoid the crowd's acclaim, Beachey increased their admiration for his exploits.

Beachey continued to set new aeronautical records and consequently received more attention. He made an unprecedented aerial crossing of the Columbia River on September 19th, carrying a message from Theodore Hardee to Constant Williams, commander of the army barracks at Vancouver, Washington. The message noted the unique form of transportation and indicated Hardee's feeling that air mail was a likely application for the airship. Beachey's return flight, however, was unsuccessful because his airship was blown seven miles to the northeast, and he was forced to land in a field. It was another indication of partial defeat. Despite the fact that Beachey was an aeronaut who possessed skill and daring, his airship often left him at the mercy of the wind. II-3I

Beachey circled downtown Portland on Sepiember 26th and landed on the top of the Chamber of Commerce Building. He made the flight so effortlessly that he suggested a regular schedule. Pauline Oelo McClay, a visitor to the fair, seemed to have the same feeling. In her personal diary she noted that Beachey's alrship was a "[strang] sight," but, "all so easy and graceful."II-32

Beachey established a personal reputaition in Portland that remained with him throughout his life. Some admiration in the Portland 
newspapers can be traced to regional boosting, but it is also true that Beachey did become one of the best airship and aeroplane pilots in the world in the subsequent nine years. Certainly, exposition officials were pleased. Hardee recommended Beachey and Baldwin to W. E. Cottre11, Governor of Works for the Jamestown, Virginia Exposition, scheduled for 1907. He maintained that Baldwin would help Jamestown if "earnest effort and hearty work counts for anything." II-33 He personally thanked Baldwin in mid-October telling him that his "earnestness and honesty of purpose" had made the venture successful. He also predicted that Baldwin had a bright future in aeronautics. II-34

The exposition paid the men over $\$ 4000$ for twenty three flights. II -35 Baldwin told readers of the Lewis and Clark Journal that the airship was out of the experimental stage, and that Beachey's flights had done more for aerial navigation than any other event. ${ }^{\text {II-36 }}$ There was no reason for Baldwin to inflate these accomplishments. He simply believed that twenty three flights in one region was very impressive. He noted that only five years before an airship could hardly be flown, let alone controlled. Baldwin belleved that airship designs would make steady progress, and he hoped that Portland's flights would help some people overcome their reluctance to consider the craft as a practical machine. "I fully realize," he said,

that the public is watching the airship with eager eyes, but we must ask of them to be patient and remember that it is in its early existence and not expect too much all at once. I feel it is a thing that must grow step by step, and every little point gained, no matter how sima11, is one more obstacle removed. II-37

The flights at Portland were significant for several reasons. Press coverage focused on the subject of aeronautics for several months 
as reporters gathered in one place to witness public experiments. Attention was focused on the aeronaut, and Lincoln Beachey was on his way to becoming an important figure in American aviation history. Beachey was examined and cross-examined by the press, and the qualities that reporters saw in him were projected upon the pilots who came after him. Beachey flew an airship until 1910 when he joined Glenn Curtiss' Exhibition Team. His reputation as a stunt pilot increased, and he flew aeroplanes at exhibitions until his death in 1915. At that time an observer said of him:

Each art has its master worker; its Paderewski, its Saint Gauderis, its Milton. There is music and most inspiring grace and prettiest poetry in flight by man in the heavens, and posterity will write the name of Lincoln Beachey as the greatest artist on the aeroplane. II-38

Oregonians and fair visitors witnessed air technology pass from its earliest stages and at the same time came to understand the limitations inherent in this kind of craft. Beachey had demonstrated that flying and controlling an airship was possible, yet even he abandoned that mode for the aeroplane. Still, important technological steps had been taken, and psychologically, many people came to believe that it would be only a short while until flying became common. Oregonians felt that their exposition had been instrumental in helping these steps to take place. "Since the Lewis and Clark Centennial Exposition," wrote Henry Reed, secretary of the exposition in 3908 , "great advances have been made in aerial navigation, the foundation for which was undoubtedly laid at Portland in 1905."II-39 They also recognized that Oregon's newspapers and publicists had significantly contributed to the growth of the aeronaut's image as a daring and courageous man. 
NOTES

CHAPTER II

1 "Has Record for Flight in Air," The Oregonian, 10 Sept. 1905, sec. 1 , p. 8 , cols. $1-2$.

2 "Airships in Successful Flights at Exposition," Lewls and Clark Journal, 4, No. 2 (1905), pp. 12-13.

3 Theodore Hardee, Lєtter to Major T. S. Clarkson, 8 July 1905, Mss. 1609, Box 15, Lot 40, No. 354. col. 2 .

4 "Race Between Airships," The Oregonian, 14 July 1905, p. 1,

5 "'ity's First Glimpse of an Airship," Oregon Journal, 18 July 1905, p. 8, col. 2 .

6 "Airship Angelus Flies Over City," The Oregonian, 19 July 1905, p. 1, col. 3 .

7 Theodore Hardee, Letter to Major T. S. Clarkson, 29 July 1905; Majur T. S. Clarkson, Letter to Theodore Hardee, 31 July 1905, Mss. 1609 , Box 15, Lot 40, No. 354.

8 "Kunaway Airship Crosses City Th1s Afternoon," Oregon Journal, 1 Aug. 1905, p. 8, cols. 1-2.

9 "Sails Over City of Toledo," The Oregonian, 28 June 1905, p. 3, col. 4; Alberto Santos-Dumont, "What I Will Do," Oregon Journal, 23 July 1905, sec. 3, p. 33, cois. 1-3.

10 "Successful Trip of the Airship Angelus," Oregon Journal, 9 Aug. 1905, p. 8, col. 6 .

11 Henry Serrano Villard, Contact: The Story of the Early Birds (New York: Bonanza Books, 1948), p. 24. 1, col. 2 .

12 "Airship Circles Falrground," Oregon Journal, 20 Aug. 1905, p.

13 "Knabenshue's Airship Sails Over the City," New York Times, 21 Aug. 1905, p. 1, col. 3.

14 New York Times, 21 Aug. 1905. 
15 "Airship Again Is King of the Air," Oregon Journal, 22 Aug. 1905, p. 8, col. 3 .

16 Major T. S. Clarkson, Letter to Theodore Hardee, 25 Aug. 1905, Mss. 1609, Box 15, File 325.

17 Henry Reed, Letter to General Press Bureau, 25 Aug 1905, Mss. 1609, Box 15, File 325. $8, \operatorname{col} .7$.

18 "This Flight Beats the World," Oregon Journal, 30 Aug 1905, p.

19 Lewis and Clark Journal, 4, No. 2 (1905).

20 "Aeronaut Beachey Has Narrow Escape from Death," Oregon Journal, 3 Sept. 1905, p. 3, cols 2-3.

21 "New Airship Has Maiden Trial," Oregon Journal, 4 Sept. 1905, p. 6, col. 7 .

22 The Oregonian, 10 Sept. 1905.

23 The Oregonian, 10 sept. 1905.

24 The Oregonian, 10 Sept. 1905.

25 The Oregonian, 10 sept. 1905.

26 The Oregonian, 10 Sept. 1905.

27 "The Airship Has Ccme," Editorial, Oregon Journal, 15 Sept. p. 4, col. 2 .

28 "Alrship Makes New Record," Oregon Journal, 15 Sept. 1905, p. $1, \operatorname{col} .1$.

29 Iincoln Beachey, "How It Feels to Sail the Sky," Oregon Journal, 17 Sept. 1905, sec. 3, p. 3, cols. 1-5.

30

Oregon Journal, 17 sept. 1905.

31 "Takes Message by Airshif," The Oregorian, 20 Sept. 1905, p. $1, \operatorname{col} .3$.

32 Pauline Oelo McClay, "My Trif to the Fair," Oregon Historical Quarterly, 80 (1979), 57.

33 Theodore Hardee, Letter to W. E. Cottrell, Governer of Works, Jamestown Exposition Committee, c/o Portland Hotal, Portlän, Oregon, 4 Oct. 1905, Mss. 16ūy, Box 16, File 354.

34 Theodore Hardee, Letter to Thomas Baldwin, 19 0ct. 1905, Mss. 
1609, Box 16, File 354.

35 Pay Schedule Document, 19 Oct. 1905, Mss. 1609, Box 16, 1905.

36 Thomas Scott Baldwin, "What the Airship Flights Have Shown," Lewis and Clark Journal, 4, No. 5 (1905), pp. 4-5.

37

Lewis and Clark Journal, No. 5 (1905).

38 Don Dwiggins, The Air Devils: The Story of Balloonists, Barnstormers and Stunt Pilots, (New York: J. B. Lippincott, 1960), p. 103.

39 Henry Reed, Official History Lewis and Clark Centennial Exposition, (Portland: n.p., 1908), p. 344 . 


\section{CHAPTER III}

THE BUILDING OF THE IMAGE

After Oregon's newspapers and magazines contrijuted to the building of the aeronaut's image in 1905, 1ittle activity related to aviation occurred in the state until 1909. Local newspapers continued to report and comment on national events, and some of the coverage was recognized to be very gocd. Fly magazine praised Eleanor Baldwin, an editor for the Portland Telegram, in January 1909 for her willingness to devote "space to aerial flight, exhibiting considerable knowledge of the subject."III-1 Other national publications covered aviation's image. They created the context with which Oregonians responded to the aeroplane.

As the aeroplane became the common flying machine after 1908, the personal qualities attributed to the aeronaut were transferred to the aviator. The inage was developed in similar ways, although there were important differences. The aviator was afforded more respect becalise his vehicle allowed an impressior of greater control. It was the aviator, flying at exilibitions, whe convinced many people that an aeroplane was easier to control than an airship and might even have practical applications in the future. The earliest public impressions were undoubtedly shaped by the appearance of the aeroplane and the incredulity that many falt as they pondered the aviator's chances. Arthur Gordon has written that, "to leave the comfortable earth on fragile wings demanded a blend of courage and curiosity, dedication and daring, fanaticism and fatalism." III-2 
The flying skills of the aeronaut and aviator were important, and a daring personality certainly helped the pilot contaln emotion in dangerous situations, but scientists and inventors realized that an aeronaut could only hope for limited control in a lighter-than-air flying machine, so they focused on questions of aerodynamic theory related to heavier-than-air machines. They understood that an excellent pilot was helpless in an unsafe machine. The heavier-than-a1r machine, or aeroplane, was the answer, but complex problems such as wind-resistance, carriage stability, and horizontal wing equilibrium needed solutions. Aviators had to test theories by flying the aeroplanes. It was a risky business at best and even more dangerous when the exhibition became the most common forum for testing. While the spirals and loops seemed foolhardy to some observers, they were necessary to test aeroplane stress. Some spectators did not realize this to be the case, and thus feelings were heightened that the aviator was a daring and remarkable man, although somewhat careless.

Aviators reacted to this hero-worship in similar ways. Gilman Ostrander has written that even Charles Lindberg resisted this imposed heroic status by asking people to honor his machine and not him. III-3 His reaction was not unprecedented in 1927. From the pioneer days of aviation, aeronauts and avlators presented themselves as machine-age men shying away from proclamations about heroism and nerve. This image grew nevertheless.

Besause Orville and Wilbur Wright delayed the presentation of. their aeroplane to the public until 1908, public awareness of its potential lagged until. that time. But the probable effects that flying, 
whatever the craft, would have on human relationships were discussed. When Lincoln Beachey crashed his airship at Cleveland, Ohio in 1906 he was still praised by the New York Times. After regaining consciousness Beachey remarked that his airship would be fine if he fixed the truss; an acknowledgement by the aeronaut that he was more interested in the technological problems than thrilling the crowd. His noble comment appealed to a Times reporter who found, something heroic about it. Courage is after all the quality of qualities. . . That there is any conscious idea of sacrifice in their heads can not be maintained, probably, for they make their airy journey partly because they enjoy them and partly because there are, or may be, money or fame as the rewards of a real success. At any rate it was really charming of Beachey to think of that truss so promptly instead of rubbing his bruises and swearing to risk no more of them. III-4

This concern about motivations became a central question by 1908 . The aeroplane promised different things to different people, and, to a degree, the aviator's character was evaluated as a factor in the future applications of the machine. Orville and Nilbur Wright hoped that the aeroplane would make war impractical, yet at the same time they made overtures to foreign governments, Insisting that, "No government dare take the risk of waiting to develop practical flying machines independent1y."III-5 Americans engaged in a consistent debate about the Insecurities of the aeroplanes' applications. This ambivalence was answered to some degree by the creation of an aviator's image that stressed daring yet responsible qualities.

In an article published in Harpers Weekly. in November 1907, Charlotte Perkins-Gilman examined the future of the aeroplane and declared that mankind's behavior had to improve su that it would never be used for destructive purposes. Ms. Perkins-Gilman was a leading 
feminist who believed constructive behavior was also the responsibility of the average citizen. She noted that mankind's only rational alternative would be "a 1ifting of the standards of humanity." "Winged," she sald, "we must be we11-behaved." Thus human ethical behavior had to evolve with technological improvements. "He [Man] cannot think of himself further as the worm of the dust," she wrote, "but as butterfly, psyche, the risen soul."III-6

The aeroplane promised to transfer passengers and merchandise at speeds which would revolutionize human relationships. The aeroplane, some feared, forced people to adfust personal lifestyles to a quickened and unnatural pace. One observer noted:

There is the further consideration of the influence of such accomplishments upon the delicate fabric of the body and soul of man-kind. Any large accomplishment of flying must mean an increased hustling and speeding up of human life; more hurry, more bustle, more breathlessness, more triumphant supremacy of material things. III-7

Some people were not confident that the aeroplane would improve human life and transform human beings into more responsible creatures. While the machine would make it possible to cross the artificial boundaries created by nations and thus be symbolic of greater interdependence, it might only "transfer to Paris an existence which has become intolerable at Peking."III-8

The aviator's image was fashiored partiaily in response to these fears. Aviators generally made public statements which suggested an awareness of their assigned role. Some aviators also argued that: aviation would free the human race and satisfy the dream to fly like a bird. Wilbur Wright remembered:

- . a sense of exhilaration in flying through the free air, 
an intensity of enjoyment, which possibly may be due to the satisfaction of an inborn longing transmitted to us from the days when our early ancestors gazed wondering at the free flight of birds and coistrasted it with their own slow and toilsome progress through the unbroken wilderness. III-9

Wright's choice of words gave an impression that he was an extraordinary man. He might have only wanted to describe his sensations in flight, but he could not help people understand what they had not experienced. Most Americans tended to accept the notion that an aviator was not an ordinary individual. Joseph $\mathrm{J}$. Corn, writing in the American Quarterly, asserted that this image of the aviator continued to be popular well into the $1920^{\prime}$ 's and was evidenced by phrases used to describe them. III-10 Claude Grahame-White, a very successful English aviator, recalled this attitude in a book written in 1930:

When for the first time... men began to $f l y$, it was generally thought that, . . one must have superhuman qualities. It was said . . . that the Wrights possessed an altogether abnormal quickness of movement, that they were not ordinary men at all. III-II

Although little doubt was expressed by 1908 that a practical aeroplane would be invented, many people looked to the figure of the brave, virtuous and responsible aviator as the eventual master of the machine. Current Literature ran a story in 1908 that asserted people would eventually learn to emulate aviators. "When the airship finally

comes into universal use," the writer said,

we may expect a unique race of people. These will be people whose daring and nerve is unsurpassed; people with a penetrating vision; with clear eyes; with steady hands; with deep lines crisscrossing the face. III-12

Writers who resisted the common inclination to praise the aviator, or those who disliked the aviator's insistence that the machine be honored more than the man, seriously discussed the problems generated by 
the coming of the aeroplane. Might the aeroplane take more from humanity than it returned? Was it proper to say that an aviator was a master of a machine? Was it possible to assert that any human being could conquer the elements? These questions are summarized in a disturbing reflection from one skeptic, who wrote:

In all our mechanical ingenuities we have constructed masters for us . . rather than servants; being compelled immediately such ingenuities have found frit in invention, to adjust our lives to the new conditions which these, and not we, have laid ufon us. III-I3

Notes of caution, however, were all but forgotten after Wilbur and Orville Wright stunned the world with their flights in August and September 1908. Wilbur flew with mastery in Paris, and all rumors that he was a fraud were dispelled. He shattered existing speed and altitude records, leading the French aviator Leon Delagrange to admit, "Well, we are beaten! We just don't exist."III-14 Francois Peyrey praised Wright in the following way:

I shall try to give an idea of the incomparable mastery of the Amcrican aviators in the marvelous art of imitating the birds. For a long time... for too long a time . . . the Wright brothers have been accused in Elrope of bluffing; perhaps even in their own land. Today they are hallowed by France. III-15

\section{Significantly, historian Charles Dolphus related Wilbur's flying} skill to his personal characteristics by notfing that "The haute personality of Wilbur Wright, his reserve and his sureness, the nobility of his character, culminated in conquering the world of aviation and the general public."III-16

Although Orville crashed and killed a passenger in 1908 during a test in Virginia, the accident seemed an exception, and public confidence in the areoplane was greatly elevated in the fall of 1908. Some 
visionarles even predicted that man would one day fly through the air without a machine. The eminently practical Thomas Baldwin was led to comment, "No one who has keenly felt the joy and triumph of flight in his own person can fall to believe in this prediction."III-17

Most observers thought such a statement exaggerated and conceded only gradual changes. A writer for the Baltimore Sun confidently

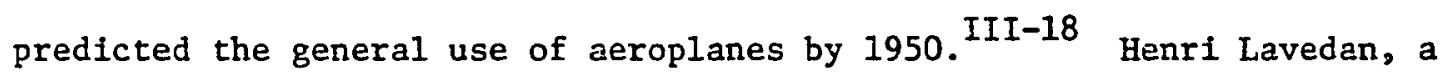
French dramatist, wrote:

I cannot fail to recognize, with an anxiety which is almost alarm, that this aerial navigation, which is preparing to invade and dishonor the solitudes of the sky, is about to drive min away from nature, in that very hour when he falsely persuades himself that he is drawing near to her. . . . The sole concern, now, will be who san go highest and swiftest in space. Little enough will anybody care for what is beneath him! Cities, mountains, forests, monuments? Mere pebbles and blots. Brooks and rivers? B1ts of white thread! Men will see nothing and enjoy nothing. Ah, when the first months of enthusiasn have passed by, what sad weariness will oppress the weary travellers. III-19

This statement came from a non-aviator. Aviators seldom lost enthusiasm for flying. Baldwin belleved that the mind's freedom was extended after long periods in the air. These conflicting images of the aviator and the machine existed side-by-side, but, by 1909, the positive one prevailed. Some emphasized the daring image of the aviator who possessed transformative powers and thus could affect the application of the aeroplane. Rhoda Hero-Dunne wrote:

How will they look upon us wingless ones? Our great aerial children soon to come? Who even nuw begin to quicken life, With movement toward their finer element And fierce essays against the weight of time . . The sunlight will be woven in their blood And breadth of spaces native to their breath
Will urge them till they roar again for joy. 1 II-20

While poetic images about the aviator were romantic and interesting, 
it was the scientific community's acceptance of the aeroplane and the aviator that gave increased weight to the argument that aviation had a practical future. III-21 Wilbur Wright knew that a good machine lessened the risk to the aviator. Like the aercnauts Beachey and Knabenshue, Wright spoke confidently about his flying machine and emphasized the positive advantages of flying rather than the risks. In fact, The Oregonian claimed in September 1908 that Wright had discovered the secret of aeroplane construction. III-22 While not a brilliant or original observation, it certainly seemed true to those who followed aviation. Whan Thomas Edison visited Portland that same month, he pointed out that major problems still needed solutions before the aeroplane could be considered a practical machine. He agreed that Wilbur and Orville Wright were good aviators, but he Insisted that a safe machine would make it possible for a man of average intelligence to fly. Although Edison's scientific appraisal deemphasized the role of the aviator, he also recognized that aviators had to be calm and courageous. ${ }^{\text {III-23 }}$

In a quest for fame and fortune people all over the country invented aeroplanes. If successful, a backyard design could propel an engineer to the top of the aviation world in 1909. Louis Wagner, of Newburg, Oregon, proudly announced to the press in March 1909 that with his design he had solved the problem of stabilizing the aeroplaue's carriage. He was so confident that he predicted flights at the Rose Festival in Portland in June. Nothing, however, was heard from him again. III-24 Others were more successful. Glenn Curtiss flew twenty five miles in July, and Louis Bleriot became the first aviator to cross the English Chamel. But most important1y, in 1909, the exhibition 
became the great testing ground for aeroplane technology. Most of the best aviators gathered at Rheims, France, for the first international aviation meet in August. It was at Rheims that the exhibition age arrived. One author has claimed that, "Before Rheims the practicality of flight was in doubt; after Rheims it was a demonstrated fact."III-2b Huge crowds watched 1300 flights without a serious injury to an aviator, though some of the airmen were very lucky to escape accident. The crowds responded in ways that became familiar to observers at aviation meets throughout the world. A reporter for the London Mail wrote:

The mad enthusiasm of the watchers was a feature unforgettable. In the open air restaurant men and women stood on tables and shouted and screamed for joy completely carried away by the ecstasy of the moment. It is only once in a liferime that one sees a great crowd so utterly beneath the influence of a single common and uncontrollable emotion. III-26

Scientific American magazine looked to the pragmatic side of aviation and praised the U. S. Aeronautical Division for its selection of men:

The selection of Lieutenants Lahm and Humphrey to be the first Aeroplane pupils is a wise one, not only because the gentlemen have had more aeronautical experience than anyone else in the army, but, because they are, both of them, the type of men to make a success of any enterprise requiring quick thinking, and action, and cool nerves. III-27

Thus, after the first international aviation meet, and before a similar show in the United States, newspapers and magazines had detated the role of the aviator and the aeroplane and generally reached a consensus that the age of aviation would be guided by a daring aviator. Even scientists had agreed that personal characteristics played a role in successfu? flight. 
NOTES

CHAPTER III

1 "Who, Why, When and Where," Fly, Jan. 1909, p. 12.

2 Arthur Gordon; The American Heritage History of Filght (n.p.: American Heritage, 1962), p. 118.

3 ostrander, PF. 268-273.

4 "Topics of the Times," Editorial, New York Times, 5 June 1906, p. 8 , coi. 4 .

5 Gordon, p. 160; and Walter T. Bonney, The Heritage of Kitty Hawk (New York: W. W. Norton, 1962), p. 64.

6 Charlotte Perkins-Gilman, "When We Fly: How the Accomplishment of Aerial Navigation Will Make Necessary a Revision of Human Laws and Customs," Harpers Weekly, 9 Nov. 1907, pp. 1650, 1664.

7 "When We Can Fly," Living Age, 22 Feb. 1908, pp. 499-502.

8 Living Age, 22 Feb. 1908.

9 Wilbur Wright, "Flying - As a Sport - Its Possibilities," Scientific American, 29 Feb. 1908, p. 139.

10 Joseph J. Corn, "Women Pilots and the Selling of Aviation," American Quarterly, 31 (1979), 558.

11 Claude Grahame-White, as quoted in Harry Harper, The Evolution of the Flying Machine: Balloon, Airship \& Aeroplane (Philadelphia: David McKay, 1930), p. 201. 9.

12 "Dawn of the Age of Flying," Current Literature, Iuly 1908; $p$,

13 Living Age, 22 Feb. 1908.

14 Charles H. Gibbs-Smith, Aviation: An Historical Survey From Its Origins to the End of World War II (London: Her Magesty's Stationery Office, 1970), p. 131 . 
17 "A Review of the World," Current Literature, Oct. 1909, p. 375. 18 Current Literature, Oct. 1909, p. 375.

19 Current Literature, Oct. 1909, p. 375.

20 Rhoda Hero-Dunne, "The Aeronauts," Current Literature, Oct. 1909 , p. 455.

21 Crouch, pp. 18, 75.

22 "Conquering the Air," Editorial, The Oregonian, 11 Sept. 1908, p. $8, \operatorname{col} .1$.

23 "Airships Crude, Edison Declares: Air Navigation Methods

Faulty," The Oregonian, 13 Sept. 1908, p. 1, col. 5.

24 "New Airship Here," The Oregontan, 20 Mar. 1903, p. 1, col. 3.

25 Gordon, p. 122.

26 Current Literature, Ocí. 1909, p. 368.

27 C. H. Claudy, "Our Aeronautical Organization," Scientific American, 13 Nov. 1909, p. 350. 
CHAPTER IV

PROMOTING THE EXHIBITION IN OREGON

Aeroplane exhibitions made aviators ramous because they were attended by huge crowds. The initial idea for exhibition tours throughout the United States perhaps came from Charles Willard, one of Glenn Curtiss' students. Both men apparently discussed the question with Thomas Baldwin who, of course, had extensive experience with airship exhibitions. Baldwin believed that public reception would be exceptional, and Curtiss began tours in the fall of 1909. Although being sued by the Wrights for patent infringement, he wanted to "influence sentiment against them." IV-1 The WrIghts quickly responded by forming their own exhibition troupe, and the competition began in earnest after the Los Angeles aviation meet in January 1910.

Exhibitions in Oregon were significant contributions to this national trend because they featured some of these excellent avlators, and they also afforded aspiring local citizens with an opportunity to build a reputation. Some Oregonians, having staged the successful promotion of the airship in 1905, passed the lesson on to others, who looked to an aeroplane exhibition as a good way to publicize the region and focus attention on the aeroplane at the same time. Thus the birdman was welcomed to Oregon in 1910 as the aeronaut had been in 1905 . Charles Hamilton, a member of Curtiss' exhibition team since November 1909, was the first professional aviator to fly an aeroplane in 
Oregon. His exhibition came in March 1910 after six months of intense activity geared to the acquisition of a man with a renowned reputation. Some of Oregon's most influential citizens participated in these negotiations, and their efforts secured the contract of a professional aviator and an aeroplane exhibition less than two months after the very first international aviation meet ever staged in the United States. Soon after the conclusion of the meet at Rheims, E. Henry Wemme, a Portland tent and awning manufacturer, announced that he wanted Portland businessmen to sponsor a similar American meet. Wemme estimated that the aviators would cost Fortiand $\$ 200,000$. He velleved thet Portland was a growing city that would benefit from the attention generated by such a prodigous gathering of important aviators. Thus, for the second time in five years, Portland promoters hoped that a flying machine would elevate their city in the eyes of the world. The Oregonian supported Wemme's aspirations:

At the present progress of aerial navigation and aero contests, next year will undoubtedly mark the opening of an epoch of aviation by heavier-than-air craft. For this reason the eyes of the whole world will be upon the theatre of the coming contests. Portland should strive for the honor of being the goal of the aviators and incidently becone the househuid word of millions of people of both hemispheres who are interested in aerial transportation. IV-2

Wemme's dream, first voiced in September 1909, proved unrealistic. Los Angeles was granted the honor of hosting the first international aviation meet in the United States, scheduled for mid-January 1910. However, Portlanci's proximity to Los Angeles offered local promoters an opportunity to entice the aviators to come north to oregon for special exhibitions. Wemme promisea in early January that Poriianders would have a surprise at their upcoming auto show at the end of the month. 
The Spectator reported that he was going to ask some competitors to come to Portland. Wemme certainly seemed to be the best person to make the effort since he had owned Oregon's first automobile in 1898, and he realized that an aeroplane would increase attendance at the auto show dramatically. The Spectator gave him its blessing, adding that the scheme was "a bold one, but it is plausible and prolific of much good if it works." IV-3

When wemme realized that an aviator could not be secured by tha end of January he tried to buy an aeroplane directly from Glenn Curtiss' plant in New York. This was an expensive proposition. Custom-built Curtiss aeroplanes ranged in price from $\$ 3000$ to $\$ 5000$ and their constant need of repair made them almost prohibitive to own if one did not also own a machine shop. Yet Wemme went about the negotiations in a way that sugge:sts he was ready to pay almost anything for the honor of owning the first aeroplane in Oregon. IV-4 He sent lengthy telegrams to the company with litile regard to the price because, "If only I can land that ship here," he said, "that is all I want."IV-5 The deal. was completed, and Wells Fargo agreed to express the aeroplane across country by rail. Only when Wemme:'s friends asked what all this was going to cost him did he inquire. Hearing that freight charges alone would approach $\$ 1500$, he immediateiy cancelled the deal and sent George W. Kleister to Los Angeles with instructions to purchase a prizewinning aeroplane directly from Glenn Curciss. The reason for Wemme's hastily made arrangements was partially explained by Oregon's newspapers when they told the story of John Burkhart, an Albany, Oregon man who was building his own aeroplane at the armory in Portland. Burkhart received training in aeronautical 
engineering at Cornell University, graduating in 1909. Fly magazine reported In its December 1908 issue that "Two Cornell students John C. Burkhart and Oscar Trolicht, have Invented a new heavier-than-air machine with which they have made some successful flights. IV-6

In the $1890^{\prime}$ 's Cornell had been the base of Robert Thurston, a man who often invited men like Octave Chanute to speak to his classes about aeronautics. Thurston trained Charles Matthew Manley. Manley was the aviator who tested Langley's aerodrome in 1903. When Burkhart enrolled at Cornell he went to a school that stressed professional englneering. Thomas D. Crouch has emphasized that aviation gained respectability in scientific circies when professional engineers serlously applied their knowledge to the technological problems of flying an aeroplane. IV-7 John Burkhart was one of these professionals; the man bullding an aeroplane in downtown Pertland was not a crank. Henry Wemme had reason to fear that he yould not be the owner of the first aeroplane in Oregon. Burkhart probably knew more about aeroplanes than any other Oregonian at that time. He met and photographed Orville and Wilbur Wright and was present the day that Glenn Curtiss won a prize from Sclentific American for his flying skill. IV-8 Will Lippnan, another promoter of the auto show, Insisted that any exhibition of aeroplanes would have to include Burkhart's ship. Wemme zeluctantly agreed.

In mid-January, Wemme announced to the press that he had purchased an aeroplane from Glenn Curtiss for $\$ 5000$. He clearly explained his motivations when he said:

My machine will be the first owned in Portland. The other one that will he exhfbited will not be fully completed by the time mine arriv's ard there is no absolute assurance that it really w111 fly. My machine has flown and is as practical in 
construction as aeroplanes are now made. I owned the first automobile in Portland and I know of one man who would giye $\$ 10,000$ if he could deprive me of that honor for himself. 10

Burkhart's reputation as a plane builder did not impress Wemme. Wemme could not personally build the first aeroplane so he bought one. He did not plan to fly it but, Instead, sent Howard Covey, a Portland automobile dealer and race driver, to Los Angeles for lessons from Curtiss. Covey had studied aeronautical thenry and jumped at the chance to learn the art of flying from Curtiss. He also hoped to convince Curtiss to give him the Northwest distribution agency for his aeroplanes. Although Covey had never flown an aeroplane, the Oregon Journal sensed that he had the qualities to be an excellent aviator. "Covey should make an ideal aeronaut." the paper reported,

He is built much like Curtiss and Paulhan; short, slender, small of bone and muscle, yet a bundle of nerves and daring. He is absolutely fearless, $y$ yet when in the most dangerous places is
cool and collected. IV-10

Reporters in Oregon had experience only with the aeronaut Beachey, and it is no wonder that their descriptions of Covey would be similar. They had not learned that it was inappropriate to refer to an aeroplane as an airship and an aviator as an aeronaut. It was also a bit ridiculous to speak of Covey as if he was an accomplished figure in the world of aviation.

Weme saved considerable expense by shipping an aeroplane from Los Angeles rather than New York. When Covey arrived in Portland on the train with the aeroplane he revealed that Curtiss had given him one eight hour lesson. Curtiss also sent Carl Fisher, a mechanic, to Portland to assemble the aeroplane. As Covey faced the press he spoke as if he had been flying all his life. He insisted that flying was very simple if 
the pilot learned how to guide the aeroplane's direction with proper body movements. A reportar for The Spectator speculated that Covey had been the perfect choice for Wemme because he had already demonstrated courage in the rodeo and by racing cars. The story continued:

Mr. Covey, who probabily has nerve enough to hang on the tail of Haley's Comet for exhilarating excercise, finds fun in his coming ride skyward and, although he, no more than anyone in these parts, does not know much about airships, he is $\cdot \cdot{ }^{\prime} \dot{V}-11$
willing to try his luck with the strarge looking machine.

Wemme's machine and Burkhart's aeroplane were exhibited at the Portland Armory during the last week in January 1910. The exhibition of fiying machines at auto shows was not uncommon. Shortly after the formation of the Aero Club of America in 1905, the members exhibited the airships of Baldwin, Stevens and Saritos-Dumont alongside automobiles in January 1906. IV-12 In Portland, the aeroplanes were enclosed in a special room, and an extra $75 c$ was charged for the right to see them. Nevertheless, 1400 people paid the money and listened to lecturers describe their operation. Wemme was surprised by the interest demonstrated by Portlanders, and he noted with delight, "Adults and children alike, manifest the most extraordinary interest in the machine."IV-13 Newspapers covered the exhibition and interviewed would-be aviators and plane builders. Portlanders learned that Wemme's machine had won five prizes under the directior of Charles Hamilton at Los Angeles. The Oregonian noted that the "curlous vehicle" crashed into the grandstands on the final day nf the meet. This event must have led to some speculation as to Wemme's reason for purchasing the aeroplane. IV-14 Burkhart's aeroplane received considerable attention. The aviator felt that his design culminated three years of hard work. He did not build aeroplanes for a hobby but believed that aviation had a 
bright future, and he wanted a role in it. He spoke of immediate applications when he sald:

I am confident that before long aeroplanes carrying 20 persons and capable of travelling at a rate of 100 miles an hour will not be uncommon. The coming summer will see marked advance in development of the length and speed of aeroplane flights. IV-I5

Wemme estimated that the auto show crowds increased by forty per cent because of the aeroplanes, and that the extra admission raised $\$ 1500$ dollars for the good roads fund. This project was Wemme's favorite as he hoped to help finance the construction of a road through the Columbia River Gorge. With this thought in mind, he agreed to exhibit his aeroplane at Meier and Frank's department store. He lowered the admission price to ten cents, hoping that a greater cross-section of people could see it on display at this fee. The Oregon Journal commended Wemme's concern for the poorer people, believing that they would benefit the most from seeing the "skyscraper."IV-16

The public's interest in these aeroplanes encouraged local promoters in their schemes to bring avlators to the state. As early as mid-January Jerome Fancuilli, Glenn Curtiss' manager, released a Lentative travel schedule for the aviator. That schedule included a stop in Portland 1ater in 1910. IV-17 Almost every day in January Portlanders read storses shout aviators and their aeroplanes, and hints that some of these great flyers were considering a stop in the city increased. They also read stories that spoke about the adjustments that flying would force them to make in their 1ifestyles. "It is almost impossible," one article suggested,

for the average citizen to picture himself a time not more than twelve months distant when the whirring of motors up in tine air wili be a familiar sound and the birdlike progress of the aeroplane a sight to which he will quickly become accustomed. 
Even if most people could not imagine consistent aeroplane flights, some already were criticizing failures. The Oregonian deplored negative attitudes, noting that "already they [aviators] have achieved more in a decade than the first navigators of the water did in twenty or thirty centuries, and yet we complain of their sluggishness." IV-19

It is difficult to identify the local promoters who were contacting aviator's managers at this early date. One contacted Kenneth Lee Barnard of New York City and received a response that indicated Bernard was lining up English and French aviators for a tour of the Northwest. IV-20 The Oregonian suggested that aviators might fly over Portland as early as February 22nd. There was so much local aviation activity that one writer said Portland had gone "aeronutty."IV-21

Theatre Magnates Calvin S. Heilig and George L. Baker were identifled in the press as aviation promoters on January 30th. They were hoping to entice Louis Paulhan and Charles Hamilton to agree to an exhibition in the city. Members of the Rose City Athletic Club had also commicated with the aviators, but their asking price was high, and negotiations were still in progress. Nevertheless, The Oregonian claimed that Portland was "on the verge of being infected by the new craze, all because invencion is rapidly perfecting the art of aerial navigation."

Some local men even formed their jwn aeroplane companies. H. W. Manning, owner of the Manning Gas Mantle Manufacturing Company, revealed that men working for his newly created Pacific Arlation Company, had built one aeroplane and now were seeking a suitable plant site to build others. IV-23 John Preble and C. W. Rekar told the press that some of Oregon's wealthiest men had invested $\$ 500,000$ in the Preble-Rekar 
Airship Company. The officers and directors of the company includea $i$. w. King of Olds, Wortman, and King department store and Grant Phegley, manager of the Salem Woolen Mills store. Preble and Rekar had tried to convince Los Angeles officials to pay shipping costs for their airship so that they could complete at the big meet, but, with the greacest aviators of the day in their city, the promoters were not prepared to finance an unknown airship. However, by mid-February the Portland men had persuaded other investors to take a chance, and it seemed their problems were solved. The machine was styled after the Zeppelin airship as a huge dirigible balloon which combined the lifting power of helicopters with the driving power of propellers. Although Preble noted that foreign governments had expressed an interest in the design, the atrship story soon was off the pages of local newspapers. IV-24

When members of the Fair and Livestock Association entered negotiations with Hamilton, progress was made. The association took a greater interest in local aviation events as well, inviting Wemme and Burkhart to test their aeroplanes on the fairgrounds. Burkhart, however, returned to his home in Albany and secured Goltra Park as his testing site. IV-25 Other Portland Businessmen capitalized on the public interest in the aeroplane. Julius Meier sponsored an aeroplane exhibition at his Pure Food and Drug Show which opened February 14th at Meier and Frank. The exhibit featured Laurence Dare, a member of the New York Aero Club. Dare travelled around the country with Henri Farman's bi-plane and seven smaller models of famous flying machines. These models included scaleddown versions of Louis Bleriot's machine that first crossed the English Channel, an Antoinette monoplane, a Santos-Dumont monoplane, a Langley 
monoplane, a Wright bi-plane, and a Chanute glider. This exhibition, combined with Wemme's, exposed Oregonians to a wide range of international aviation technology. An advertisement for Moler's free exhibition emphasized the rare opportunity provided to Portlanders. "we invite your attention to this important event," the advertisement read, "knowing that it is a timeiy subject, and one which the people of Portland feel justly proud to being the first to have the opportunity of seeing." IV-26

Oregonians learned that their intense interest in the aeroplane was paying dividends when Charles Hamilton's manager, after a meeting with Portland's Retail Merchants Association on February 21st, agreed to a proposal submitted by the Fair and Livestock Commission. Charles Hamilton was coming to Portland with an undisclosed contract that required him to make flights from March 5th through the 7 th. The Oregon Journal excitediy reported that local aviators were preparing to challenge Hamilton, and that "aeroplanes, famous ones, local ones that hope to be famous, impossible ories, and, in fact, aeroplanes of every description... will fly."IV-27

D. 0. Lively was appointed publicity chairman for the exhibition with headquarters at the Oregon Hotel. Lively believed that Oregon's untested aviators could compete with Hamilton because men like Manning kept praising their new inventions. Lively foined with Wemme, M. C. Dickinson, and George W. Joseph to form the Portiand Aeronautic Club. This club offered Hamilton $\$ 1000$ if he broke the vorld's long distance record of thirty five miles established by Louls Paulhan. They even proposed that the aviator set the record by circling Mt. Hood. IV-28 
Local newspapers lmmediately started building Hamilton's image. One tabloid called him a "genius of the clouds and conqueror of the forces of nature."IV-29 Lively supported this claim by stating that Hamilton planned a fifty mile flight. Hamilton wired a message to Portland and challenged local autoists to a race with the words, "the auto must give way to the aeroplane in the matter of speed and it must settle back among the has-beens, as the world's fastest transporter of humanity."IV-30 This image building was not only for Hamilton's sake. Portland promoters believed that acquisition of his contract was a sign that the city had matured. But this sense of regional maturity was only one justification for attempts to bring an exhibition to a local area. John W. R. Taylor and Kenneth Munson have contended that "a great flying meeting in the years before World War I afforded spectacle, education, - - aerial inftiation and employment to tile professional exhibition pilots. . . "IV-3I Liveiy recognized that Hamilton was a key reason for all the excitement, and he praised the aviator saying, "nothing seems to daunt him, or in any way shatter his splendid nerve."IV-32 A writer for the Evening Telegram best expressed the city's pride when he exclaime?, "At last, Portland has come to it." IV-33 The publictty chairman was also amazed that all of this activity had occured in such a short time span. He wrote a poem that captured his wonder:

The town is catching aviation Busting laws of gravitation, The sky is filled with aeroplanes $\mathrm{IV}-34$

Posters advertising the exhibition were sent all over the Northwest, and one observer could not recall "as lavish an outlay of paper and printers 1nk."IV-35 Governor Frank Benson was Invited and Laurence Dare, 
of the New York Aero Club, remained In Portland to see the show. Marion Maus, Commander of the army barracks at Vancouver, Washington, planned to assess milftary applications of the aeroplane. It seemed that it was only a matter of time until Oregonians would be "salling over tall buildings, encircling the sumit of Mt. Hood, and accomplishing other notable feats."IV-36 As a special incentive local aviators were promised $\$ 1000$ if they circled the fairgrounds in a heavier-than-air machine and a $\$ 200$ bonus if their aeroplanes reached an altitude of 200 feet. Hamilton was surely the star attraction, but Lively hoped to surprise him with the quality of the local aviators.

But most attention was paid to Hamilton. His aeroplane was a "new creature of the air.. . endowed with life.. . so responsive was it to the slightest indicated wish of the controlling power." IV-37 Hamilton was the controlling power; pictured almost as a magical man-a man who had seen the world from a higher perspective and came away with a feeling of responsibiitty to the rest of markind. For some observers in 1910 the aviator offered hope that a better world was coming. The presence of General Maus, however, also hinted that military applications for the aeroplane were being considerec. Nevertheless, the overriding atmosphere in Portland remained festive. The Oregonian reported that "Society is evidencing an unusual interest in the new game, that promises with time to become one of its fixed fads." IV-38 Hamilton's exhibition was very significant. By early March law suits filed by the Wrights nad forced Curtiss and Paulhan to temporarily quit touring. Hamilton was the only aviator making exhibition flights in America. IV-39 This encouraged members of national photographic 
concerns to come to Portland and document Hamilton's "famous glide; how he made his aeroplane battle against opposing winds."IV-40 These photographers had often seen aviators and had greater expectations than most Oregonians. One local paper reported that to satisfy the camera buffs, "Hamilton must show by his evolutions that he has perfect control of his machine, that he can turn it or raise it, or hold it to any given course with perfect accuracy."IV-41

The aviator arrived in Portland on March 3rd and was greeted by members of the Aeronautical Club with one notable exception. E. Henry Wemme had taken 111 and gone for special treatment in Arkansas. The man whose suggestion had led to an aviation weet in the first place was not present to see it. Wemme did, however, wire a hope that Hamilton would take his aeroplane into the air first, thus assuring the Portland businessman the honor of owning the first aeroplane to fly in Oregon. Hamilton was pursued by reporters, and he graciously granted interviews. He mentioned that he had been born in Hartford, Connecticut in 1881, and he recalled his personal experiences with the aeroplane. He failed to note that his initial experience was in one of Curtiss' aeroplanes without the aviator's permission. Curtiss was giving exhibitions and Hamilton simply got into one of the planes and flew it around the track near the factory. Curtiss, called to the location by other workers, was astounded that a man could just get into the aeroplane and fly it. Ha retained the first-timer on a contract. IV-42

Reporters were most interested in Hamilton's appearance. The aviator was only five fee: seven inches tall and weighed 125 pounds with large wing-like ears as his most distinguishing feature. Despite the 
aviator's small stature a writer was positive that he possessed a "bundle of nonchalant nerve." IV-43

Hamilton expressed an opinion that aviation success was related more to the construction of the aeroplane than the character of the aviator. He explained that aviation was a new science, and he asked the public to be patient. Yet, like so many aviators, Hamilton implied that he was not an ordinary man. In one interview he noted:

Sky-sailing gets to be ordinary everyday business that you never get used to. At the same time I feel better up in the air, and away from all the clanging, screaming, snorting, contrivances that shattor the nerves. One feel 1 detached from the earth but it is a gratifying detachment. I

hamflton did not want to Imply that detachüent dulled his sense of adventure. He recognized that danger was a big factor that attracted crowds. He advertised this element by saying "I expect spills. In fact it has always seemed to me that the aeroplane didn't act just right until it had a rip or two in its planes."IV-45 Although Hamilton was an accomplished aviator, he was a poor prophet. He predicted that the aeroplane would never go much higher than 4000 feet because there were "1imits set by nature on the heavier-than-air machines' altitude."IV-46

Hamilton was ready by March 5 th because he could stop talking and start flying. He learned that Portland's avtators were not going to challenge him in the air. John Burkhart was at the exhibition, but he kept his aeroplane in Albany. Thousands of people jammed the streetcar system in efforts to reach the Rose City Country Club Track where the meet was held. An Oregonian reporter noted that people were less riotous than ball-game crowds and seemed to share a "feverish desire to get there and witness the wonderous performance of this new conqueror of the 
air."IV-47 Hamilton did not disappoint the crowd. He made six perfect flights that day. He did not attempt to set new world records, but he impressed the crowd by circling the race track and waving to them. One observer saw that Hamilton had a peculiar effect on the people:

They did not cheer, these people standing on the ground, for the man-bird soaring above their heads. Here and there a man or woman voiced short-breathed applause, but for the most part the
big crowd stood with craned necks and gaping mouths. . . IV-48

Various commentators referred to the first day of the meet as an extraordinary spectacle. It was hard for them to imagine a man in control of the weird-looking machine. The event was strictly a one man show for Hamilton, as his performances compietely overshadowed the efforts of the local men. Hamilton had satisfied E. Henry Wemme's request that his aeroplane be the first into the sky, but he landed quickly, saying that it was a very unsafe machine. Against Hamilton's advice a young Portland man, Walter Donnelly, tried to fly the Wemme aeroplane. Donnelly crashed into the crowd, injuring several people. A writer for the Evening Telegram accused Donnelly of stage fright and termed the aeroplane feeble and incipient. IV-49 In comparison it was noted that "Hamilton uses every power of body and mind in governing his aeroplane. He must think and act at the same time."IV-50 spectators at the exhibition also noticed that Hamilton was enjoying himself. On the meet's second day a reporter observed that Hamilton raced an automobile, landed in front of it on the track and took off before it could catch him. This stunt received the loudest cheer but all the while "Hamilton sat in his seat. . his thin-set face strangely like an eagle, siow moving, turned slightly in the direction of the applauding throng, the 
only recognition of it he gave."IV-51

While many Portlanders had been "inoculated by the airship germ," few paid for the privilege. IV-52 The Portland Fair and Livestock Comnission originally asked for a two dollar admission fee to Country Club grounds. Ninety per cent of the people stood outside the gates or perched on nearby "Tightwad Hill." The price was lowered as the meet progressed, but most still remained outside. Hamilton, however, came to Portland with a guarantee, and he was not the financial loser. The promoters hoped to ofisec hamilton's fee with the paid admissions, but instead they lost money. An editor for The Spectator was ridiculed by his friends after paying admission the first day, so he dectded to join them outside for the second. He remarked that those who refused to pay missed more of the meet than they thought they did. Hamilton's famous death-dive in which he pulled out of a dive right above the ground, was visible only from inside the gates. Most importantly, he believed that Portlanders had demonstraced a lack of appreciation to the members of their business community who were forced to make up the losses. "Hamilton's mastering the air," he said, "was the most interesting sight the people of Portland have ever seen."IV-53 It was a shame, the editor mused, that the people who made the meet possible lost money and might be less than anxious to sponsor another one.

Hamilton, however, left Portland on March 8th with his money. Portlanders had seen a magnificent show. While E. Henry Wemme was remembered for his initial promotion of an aviation meet, and other business men were congratulated for their willingness to absorb financial reversals, Hamilton was the man who received the greatest praise. He was 
the first real birdman to visit oregon, and those who followed him were always expected to meet the standard that he had established. 
NOTES

\section{CHAPTER IV}

1 Howard Lee Scamehorn, Balloons to Jets (Chicago: H. Regnery, 1957), p. 57.

2 "Wemne Plans to Get Air Contests," The Oregonian, 5 Sept. 1909, sec. 4, p. 5, col. 1 .

3 "Auto Honks," The Spectator, 8 Jan. 1910, p. 12.

4 "Sky Craft Draws Curious Throng," The Oregonian, 25 Jan. 1910́, p. $14, \operatorname{col} .1$.

5 The Oregonian, 25 Jan. 1910.

6 "Who, Why, When, and Where," Fly, Dec. 1908, p. 15.

7 Crouch, pp. 18, 75 .

8 John Burkhart's photograph albums, vols. 1-2, Multnomah County Library, Portland, Oregon.

9 "Two Aeroplanes Ready for Show," The Oregonlan, 22 Jan. 1910, p. 18 , cols. $1-2$.

10 "Covey Studies Aviation," oregon Jourral, 23 Ian. 1910, sec. 7, p. 15, cols. 1-3.

11 "Auto Honks," The Spectator, 29 Jan. 1910, p. 15.

12 Augustus Post, "Aero 61 ub of America Founded in 1905," Fly, Nov. 1908, p. 10.

13 "Curtiss Aeroplane Coming Downtown," Oregon Journal, $30 \mathrm{Jan}$. 1910, sec. 2, F. 7, cols. 1-2.

14 The Oregonian, 25 Jan. 1910.

15 "Local Decigner Has Built an Aeroplane," Oregon Journal, 26 Jan. 1910, pp. 1, 3, cols. 2-3.

16 Oregon Journal, 30 Jan. 1910.

17 "Skymen Include Portland in Plans," Oregon Journal, 15 Jan. 1910 , p. 4, col. 2. 
18 "Aeroplane Factory Rising," The Oregnnian, 9 Jan. 1910, sec. 4. p. 6, col. 5 .

19 "Perils of the Air," Editorial, The Oregonian, 16 Jan. 1910, sec. 3, p. 6, col. 1 .

20 "Airships to Soar Over City During Rose Festival Week," Oregon Journal, 23 Jan. 1910, p. 1, cols. 5-6.

21 "Air Full of P1ens to Make Airships," The Oregonian, 30 Jan. 1910, sec. 3, p. 10, col. 1 .

22 The Oregonian, 30 Jan. 1910.

23 The Oregonian, $30 \mathrm{Jan} .1910$.

24

"Aviators Renew Promise to Fly," The Oregonian, 3 Jan. 1910, p. 12, col. 5; "Meet is Deprived of One Alr Entry," The Oregonian, 9 Jan. 1910, sec. 4, p. 12, col. 1; "Debt Hits Airship," The Oregonian, 17 Jan. 1910, p. 9, cols. 5-6; "Now Almost Certain Portland Will See Aircrafi in Action," Oregon Journal, $30 \mathrm{Jan}$. 1910, p. 6, cols. 2-3-4.

25 "The Flyers Here," Albany Democrat, 11 Feb. 1910, p. 3, col. 2; "Wi11 F1y at Albany," Albany Democrat, 11 Feb. 1910, p. 3, co1. 5.

26 "Aviation Sale at the Greater Meier and Frank Store," Oregon Journal, $20 \mathrm{Feb} .1910$, p. 12.

27 "Airships Will Fly Over the City for Three Days," Oregon Journal, 22 Feb. 1910, p. 1, col. 7.

28 "Hamilton Sure He Can Make Records:" Evening Telegrau, 26 Feb. 1910, p. 21 , col. 5 .

29

Evening Telegriam, $26 \mathrm{Feb}$. 19i0.

30 "Aviator Hamilton Challenges Autolsts to Race," Oregon Journal, 27 F $\approx b .1910$, p. 8, cols. 3-4-5.

31 Taylor and Munson, p. 102.

32 "Seattle and Spokane Will Enter Big Aviation Meet," Oregon Journal, $28 \mathrm{Feb} .1910$, p. 2, cols : 3-4.

33 "Auto Will Race Against Airship," Evening Telegram, 1 Mar. 1910. p. 5, col. 3 .

34 "Hamilton Bent on Making New Record," Evening Telegraü, 2 Mar. 1910, p. 8, col. 3 .

35 Evening Telegram, 26 Feb. 1910. 
36 "Local Firm Agent for Aeroplanes," Oregon Journal, 27 Feb. 1910, sec. 4, p. 6, col. 1 . col. 1.

37 "The Portland Air Flights," Oregon Journal, 1 Mar. 1910, p. 8, 38 "Skycraft Arrives," The Oregonian, 2 Mar. 1910, p. 20, cols. $1-2$.

39 "Portland to See Aeroplanes Today," The Oregonian, 5 Mar. 1910, p. $12, \operatorname{col} .5$.

40 "Hamilton Arrrives Today; Promise to do Famous Glide With Aeroplane," Oregon Journal, 3 Mar. 1910, p. 1, cols. 3-4, p. 4, col. 3.

41 Oregon Journal, 3 Mar. 1910.

42 Clara Studor, Sky Storming Yankee: The Life of Glenn Curtiss (New York: Stackpole Sons, 1937), p. 198.

43 "Aviator Hamilton Longs to Live Among Clouds," Oregon Journal, 4 Mar. 1910, p. I, cols. 4-5-6.

44 Oregon Journal, 4 Mar. 1910, p. 1.

45 "Portland Will Be Center of Aeroplane World for Three Days," Oregon Journal, 4 Mar. 1910, p. 4, col. 4.

46

Oregon Journal, 4 Mar. 1910, p. 1.

47 George Keller, "Hamilton Thrills Crowds by Flights," The Oregonian, 6 Mar. 1910, p. 1, col. 7, p. 8, cols. 1-3.

48 "Manbird Amazed Thousands: View Flights in Awe," Oregon Journal, 6 Mar. 1910, p. 4, cols. 1-2.

49 "City Inoculated by Airship Germ," Evening Telegram, 7 Mar. 1910, p. 1, col. 2, p. $8, \operatorname{col} .5$.

50 "Man May Soon Pass Bird in Air," Oregon Journal, 7 Mar. 1910, p. 7, col. 3 .

51 "Crowd of 50,000 Watches Man Soar," The Oregonian, 7 Lar. 1910, p. 1 , col. 3, p. 10, cols 3-7.

52 Evening Telegram, 7 Mar. 1910.

53 "The Flying Machine Flies," The Spectator, 12 Mar. 1910, p. 4. 


\section{CHAPTER V}

\section{LOCAI BIFDMEN FLY}

Although Oregon's local aviators had not established reputations as a result of Hamilton's appearance in the state, they had a standard by which to judge their fledgling skills. Hamilton's personality exuded confidence, and his flying performances demonstrated why. This chapter will study the Oregon aviators as they responded to Hamilton's challenge. John Burkhart was a first-rate engineer, but he chose to build his aexoplane in private and tc fly at small fairs. His concern was ever directed to practical applications for the aeroplane, and he seldom sought the spotlight. H. W. Manning and his sons began a two year investment in aeroplanes shortiy before the Hamilton exhibition, an investment that involved building aeroplanes and going to exhibitions. They, however, were unsuccessful in their ventures for the most part. Eugene Ely, undaunted by the negative appraisal of the Weme aeroplane, learned to fly with that machine and gained national fame as one of the best aviators of his generation. These men had similar experiences as they struggled to become successful aviators, and each was judged by a professional standard established by men like Hamilton.

These Oregon aviators flew their aeroplanes in an era when the exhibition was a popular setting for demonstrating flying skill. Oregon's communities occasionally sponsored nationally-known aviators, but most exhibitions were local affairs that provided local aviators opportunities to fiy in public. While most local aviators throughout the country ended 
their careers in failure, some gained the laurels awarded for success.

John Burkhart and his mechanic William Crawford decided to work with their aeroplane at Albany, Oregon, in February $1910 .^{\mathrm{V}-1}$ In this choice the men remained at home and away from the public glare. Although Burkhart built his aeroplane in Portland, he never told the press about it; they came to him three months after the project had been started. Newspapers immediately began to play up a competition between Burkhart and Wemme for the honor of owning the first aeroplane lin Gregon. Burkhart really had little finterest in such honors. He had already built and flown an aeroplane in New York as early as 1908, and he had rubbed elbows with the best aviators in America. E. Henry Wemme's personal competition seems to have been all his own. Burkhart was more interested in a practical aeroplane and less concerned about the significance of it being the first in Oregon.

Yet, even though Burkhart was not the first aviator to fly an aeroplane in Oregon, he was the first Oregonian to build his own plane and fly it in the state. His success came on April 9, 1910 in Albany. He flew the aeroplane that had been exhibited in Portland. It was not an exceptional flight, but the aeroplane lifted from its skids at Goltra Park and flew several hundred yards. Burkhart's landing was rough, but the flight qualified his aeroplane as the first local plane to go skyward. $^{\mathrm{V}-2}$ Although the flight received some attention, it, ironically, was obscured by the glare of Hamilton's achievements.

Burkhart built better aeroplanes in 1911 and 1912 and flew them at county and local exhibitions throughout the state. He served as an editor for Aeronautics magazine in 1911, a publication recognized for its 
reporting of aviation news. He helped several Oregon aviators in their efforts to become successful. Louis Barin, in particular, received help from Burkhart, and was flying an aeroplane partially designed by him in 1914 and 1915. Barin then joined the service in World War I and became one of the finest aviation instructors in the navy. In 1919 Barin participated in an attempt to cross the Atlantic Ocean. $\mathrm{V}-3$

Burkhart was more than willing to share his knowledge with younger aviators. He often met with Portland's flyers to discuss technical problems and to develop solutions for them. ${ }^{\mathrm{V}-4}$ Burkhart made public flights over Portland in 1913 to interest local investors with a plan to build an aeroplane production plant on the site of present-day Benson High School. The Oregonian made an interesting observation about Burkhart in 1913 when it said:

He is not the usual type of aviator, the daredevil sort of chap intent on eliciting expressions of amazement or horror from spectators by Cangerous maneuvers, but follows the sport for scientific reasons. $\mathrm{V}-5$

Burkhart found little comminty interest in the plan in 1913, and he had to locate other outlets for his aviation skills. During World War I he was an aviation instructor for the army, but, upon his death in 1926, his contributions to the growth of aviation in Oregon were 211 tut forgotten. His obituary in The Oregonian barely mentioned that he was an aviator. ${ }^{\mathrm{V}-6}$ During the 1920's and 1930's Burkhart's partner, William Crawford, wrote to newspapers correcting numerous mistakes they reported about the chronological development of Oregon aviation history. ${ }^{\mathrm{V}-7}$ It was not until 1947 that Burkhart was awarded adequate recognition. V-8

In contrast to Burkhart, a trained scientist and engineer, $H$. W. Manning had little experience with the theory or reality of aeroplane 
design until the exciting time when Weme picqued everyone's interest with his plans. As the owner of the Portland Gas Mantle Manufacturing Company, Manniing had excellent financial resources to back his venture. His three sons built an aeroplane named the Comet I, but Jack Manning's first tests were unimpressive. They, however, convinced him that a larger aeroplane was necessary, and the Comet II was built. The Mannings scheduled exhibitions before gaining expertise as aviators, and, by the summer of 1910, they had to break a verbal contract to fly at Portland's Rose Festival. Jack Manning agreed to perform exhibitions in Astoria during July, and the flights were advertised by the Astoria newspapers. The Morning Astorian devoted copy to national and international aviation events, but no record of Manning's accomplishments can be found in that newspaper in July. ${ }^{\mathrm{V}-9}$ One recent source does mention that Manning had at least one excellent flight on July 6 th, but that flight occurred July 16 th and was covered in brief by the Daily Budget. $\mathrm{V}-10$

The Mannings established a testing base in Lakeview, Washington in August, and they hired Bruno Seibel, a California race driver, to pilot Comet II. Their hopes that a race driver would be a good aviator were dashed when Seibel was severely injured in an accident. H. W. Manning defended his aeroplane after the accident, claiming that it was the first one built on the west coast that had actually flown. ${ }^{\mathrm{V}-11}$ One day after the accident Manning displayed a sober attitude as he realized that Selbel might die. He even intimated that he would quit the aeroplane bustines5. Such a decision would be a death blow to the Pacific Aviation Company, because Minning tas tìe principle stockholder, and his support was essential if his sons ever hoped to be renowned aviators. ${ }^{\text {V-12 }}$ 
Selbel's condition, however, improved, and he blamed himself for the accident rather than the machine. Manning was then more optimistic about his aeroplane and decided to continue the investment. The investment included an active aeroplane supply business in Portland which sold materials to buyers throughout the West. The Oregon Journal reported that some of the materials included, "silk to cover the planes - . bamboo and steel ribs, and white pine, and propellers, and a dozen other things." $\mathrm{V}-13$

Still hoping for success, the Mannings built a third aeroplane and contracted to $f l y$ at the Portland Fair and Livestock Exposition in September 1910. They contracted with the organization that had sponsored Hamilton, and the exposition officials expected no less spectacular performances from the Mannings. Portland's newspapers heavily advertised the event, and The Oregonian finished its article about fair programming on September 5 th with the words:

The sight which always holds a moc'ern throng spell-bound has been held for the last number of the afternoon programme. That is an aeroplane flight in a Curtiss bi-plane. . . . The people attending the falr may have an opportunity to witness for themselves a real aeroplane flight. $\mathrm{V}-14$

The exhibition was a flop and demonstrated the wide gulf between the professional Hamilton and the amateur Mannings. Despite four days of reasonably good weather, Comet III never rose into the air. The Oregon Journal had little mercy on the Mannings as can be seen from the following report:

The most important fallure was in the aviation promises. The Manning brotieres ind contracted to fly every day, and this feature had been advertised. The management declared their absolute faith in the flights when weather permitted. . . but nothing . . . was accomplished, and the expectant spectators had to forego the fruition of pleasant anticipations. $V-15$ 
Newspapers that shaped an aviator's image could also tear it down. The exhibition was an excellent opportunity for the Mannings to prove themselves in the Northwest, but they failed to fulfill their contract and were ridiculed instead. Later in the year J. W. Depreis, an aviator hired by the Mannings, was considered a suspect in the disappearance of an aeroplane from the Commercial Club in Sutherlin, Oregon. The Mannings had recelved less than rave reviews from local newspapers after their first year of operations. ${ }^{V-16}$ Yet the men doggedly pursued their aviation dreams into 1911.

During Easter weekend they tried the exhibition circuit in Victoria, Canada, and, as usual, they were not well received. The Victoria Froyince had uncompliuientary words for Brownie Manning:

Cold feet was the common complaint with the aviators at Minerva Park yesterday. Aerial navigation, the dream of the prime romancer of the boyhood days, was nearly brought into vivid realization when Brownie Manning . . . In an attempt to break the height record for aeroplanes, rose about four feet off tine ground, and then, afraid that he really was going up, he altered his plans and made $a$. ick return to terra firma, ran into a fence, and damaging hts wings, ending by nearly making a record of another kind - - a mad rush from his machine as though it were haunted. $\mathrm{v}-17$

Frank Ellis, chronicler of British Columbia avlation history, had a kinder evaluation of the performance. He blamed many aviation fatalities on excessive public demands that forced an aviator to keep trying for success, "against his better judgement, and .. . to his death as a consequence." $\mathrm{V}-18$ Ellis credited the Mannings with good sense when they packed their bags and returned to Portland.

After elghteen frustrating months H. W. Manning hired a professional aviator to fly his aeroplane. With competition from the likes 
of Glenn Curtiss and the Wrights, Manning perhaps came to the conclusion that "the business of designing, constructing, and flying for public performances . . [was] a job for trained professionals rather than amateurs." V-19 Charles WaIsh, the owner of the 118th aeroplane license issued by the Aero Club of America, came from Los Angeles on a contract with H. W. Manning. The Portland press was invited to his debut at the Rose City Country Club on May 22, 1911. He had a fine flight, easily surpassing Hamilton's endurance record over the city. Walsh also flew his aeroplane directly over downtown Portland, and, on one flight, he carried Roscoe Fawcett, the sporting editor for The Oregonian. Fawcett's account of his experience is excerpted from his article the next day and reads in part:

The sensation of aeroplaning is much like automobiling with the bumps and bruises left out. . . . The 40 foot stretch of canvas mounted gracefully into the air after skimming along the ground for 100 feet, and for the next few seconds the grass faded away into one green kaleidoscope, while an ordinary bullpup assumed dashhund proportions fudged from the whizzing plane. -20

Later in that same week Walsh carried Miss Vida Perrin, a vaudeville actress, into the air with him. Miss Perrin compared her initial experience in an aeroplane to that of opening day of a show. She had a sense of participation in a historic event and was surprised by Walsh's calm demeanor in the air. "Most of the time Mir. Walsh was chattering away with me," she said, "as unconcernedly as starting an automobile trip." $\mathrm{V}-21$ With this comparison in mind Miss Perrin was quick to note that an automobile was less dangerous and more like, "going to market in the old farm wagon without any grease on the axles." $\mathrm{V}-22$ 
Walsh vindicated the Manning aeroplane during his week-long exhibition. Four thousand people watched him fly on May 28th as he completed two successful flights which lasted 15 minutes. After spending $\$ 20,000$ in the aeroplane business H. W. Manning had finally seen one of his aeroplanes perform well. He also realized that much of the success was related to Walsh's ability as an aviator. Even Jack Manning, when asked if he wanted to get back into the aeroplane, preferred to "leave that to Charlie." $\mathrm{V}-23$

Pacific Aviation company moved to Vancouver, Washingtion in .Tune 1911, and Walsh spent the summer in exhibitions at Seattle and Centralia: Washington, and Albany and La Grande, Oregon. He also gave the people of Vancouver their first view of an aeroplane and talked with a local reporter about his notion of flying. The following comments are similar to what observers had come to expect from successful aviators: "I never feel at 311 nervous or frightened," said Walsh, "If a fellow follows his machine thoroughly and has the requisite nerve he would never be injured very bad1y." $\mathrm{V}-24$

Walsh also shared the idea, so common with aviators, that almost anyone could learn to fly. While in the Northwest he promoted aeroplane safety by testing a new device designed by a Portland man to automatically balance the wings in the wind. Walsh declared that the invention, termed the Ellsworth Equalizer, was useful equipment. $\mathrm{V}-25$ But Walsh was an aviator with greater ambitions than exhibitions in the Northwest. He left the Mannings to join Glenn Curtiss in 1911, and his departura effectively spelled the end to the Mannings' active role in aviation. Although onc of their aeroplanes remained at the Vancouver 
Barracks into the sumer of 1912 , their role in aviation faded in the Northwest. The Mannings achieved only limited success until t:.ey acquired Walsh's contract, yet they had greater fortune than most private investors in the aeroplane. Charles M. Thomas reviewed the book Miracle at Kitty Hawk and was impressed by the Wrights" lack of compassion "for those who failed."V-26 Wilbur Wright identified the fine line between success and failure in aviation when he remarked:

Those who failed for lack of time had already used more time than was necessary; those who failed for lack of money had already spent more money than was necessary; and those who were cut off by accidents had previously enjoyed as many lucky escapes as reasonably could be expected.

Charles Walsh had demonstrated that he was a professional aviator. But he also met his death in an accident at an exhibition in October 1912; the accident proved once again that even the best aviators were vulnerable.

Oregon also produced an aviator who rose to the pinnacle of the aviation world. Eugene Ely, a young automobile mechanic in Portland, sought the public arena as an aviator and established a personal reputation which assured nim a place in the American Aviation Hall of Fame. Although Ely was not born in Oregon, he came to the state in 1909 at the age of 23. He started work for Ralph Simpson, of the Auburn Automabile Company, and quickly demonstrated his mastery of the automobile engine. After a short period Simpson invited Ely to become his partner. Ely accepted, and the partnership proved fortuitous in his early experiments with the ae: plane. The men approached E. Henry Wemme several times with an offer to buy his aeroplane, but only after the Marct 1910 meet did Wemne give Ely an option to test the plane and make 
exhibitions if initial tests proved successful. Ely's tests, made at the Twelve Mile House, were failures, because the aeroplane was originally built for Charles Hamilton, a man who weighed fifty pounds less than Ely. Even though Fly could not lift the aeroplane into the air, a reporter for The Oregonian made a prophetic comment by observing that Ely seemed to have "unusual aptitude" as an aviator. $\mathrm{V}-28$

Undoubtedly Ely received financial assistance as he tried to fulfill his personal ambitions. The sources of his income are unclear, but he had to ilave slipport when he made the decision to ship the aeroplane back to the Curtiss plant to be rebuilt. The aeroplane was constructed at the Curtiss factory, and certainly this factor led to their agreement to work on 1t. Ely scheduled a few exhibitions on the way east, which only proved his conclusion that the aeroplane needed attentiou. The Medford Mail reported in late May 1910 that Ely and Whipple Hall, an aviator from California, would fly in their vicinity on June 3rd and 4th. The paper advertised the meet as the biggest aviation spectacle on the west coast since the great show at Los Angeles. Poor weather, however, turned it into a partial fallure. The people of Medford were not completely disappointed, though, as a local judge, E. E. Kelly, apparently flew an aeroplane over the city's main street. The flight was unannounced, and thus poorly attended, but it inspired someone to write a few lines honoring Kelly's achievement. The people in the city became familiar with the song:

Has anybody here seen Kelly?

$\mathrm{K}$ - E - double - L - Y?

Has anybody here seen Kelly?

Kelly, who tried to fly?

His start was fast, he rose sublime, And how that darn machine did climb, 
Has anybody here seen Kelly?

Kelly with the overland car? ${ }^{\mathrm{V}-29}$

The aviation meet seemed anticlimatic in comparison. Ely never forgot his disappointing introduction to aeroplane exhibitions. He vowed to return to Medford and show the local people that he was a good aviator. Failure was common at aviation meets, and few people expected Ely to keep his promise.

The general qualities possessed by successful aviators were wall Identified by June 1910. James Colewell, of the United States Patent Office stated that, "The man of indecision, poor judgement, weak nerves or slow judgements is as much out of place in an airship as a defective motor." $\mathrm{V}-30$ Colewell articulate the impressions of his generation. Aviators were admired as special people because they remained calm in stressful situations. They lived a life of intensified challenge where one mistake could be fatal.

Eugene Ely felt that he had the necessary qualities to become one of the better aviators in the world. Simpson and perhaps Weme must have agreed because Ely was able to travel east with the aeroplane. On his way he made a futile series of exhibitions at Winnepeg, Manitoba and came to the attention of the New York Times which romarked after one flight that Ely was picked up in a "dying condition." $\mathrm{V}-31$

Yet, if so, Ely recovered quick1y. He appeared in New York in midAugust, preparing flights with aviation luminaries such as Glenn Curtiss, J. C. Mars, Charles F. Willard, and J. A. D. McCurdy. Glenn Curtiss scheduled a major exhibition to see if New Yorkers were willing to support aviators with as much enthusiasm as in France. Ely participated in the first simultaneous appearance of four aeroplanes in the air. The 
aeroplane is hard to identify, but he made a positive impression on Glenn Curtiss; an impression even more amazing considering Ely had not lifted an aeroplane into the air until the previous June. Ely realized that Glenn Curtiss had resources to assure his advancement in aviation if he could prove his skill to the master.

By entering Curtiss' aviation circle, Ely gained opportunfties to Increase his national exposure and fame. He won the right, in a lottery with other Curtiss flyers, to be the first man to attempt a flight from Chicago, Illinois to New York City. The New York Times sponsored this contest and covered it thoroughly. Curtiss lent Ely his Rudson River Flyer, and, as the aviator entered the aeroplane, he offered his friends a smile which "combines modesty with quiet seif-assurance." $\mathrm{V}-32$ Unfortunately his smile could not fly a broken aeroplane, and Ely abandoned his historic flighic after repeated difficultles. With the determination that he displayed in Medford, Ely said, "I will do it again. "V-33

Ely did not fall when he was awarded his next chance for recognition. While making an appearance for Curtiss in Viryinia in November, 1910, E1y flew his aeroplane from the deck of the scout cruiser Birmingham in Chesapeake Bay to a landing on the Wilioughby Spit. His flight marked the first time that an aeroplane had left a ship at sea and landed on dry ground. He completed the land to ship cycle in San Francisco the following January, when he landed on the deck of the Pennsylvania in San Francisco Bay. The navy lmmediately recognized the wartime implications of Ely's stunt. It was made possible by an idea developed by Charles Willard, another of Curtiss' aviators, who destgned an arresting gear 
which allowed the aeroplane to stop on the deck of a ship. ${ }^{-34}$ Ely was pleased, proclaiming his confidence by declaring, "I think the trick could be turned nine times out of ten." $\mathrm{V}-35$ His accomplishment lent weight to the argument that an aeroplane had practical applications, if only in war. A New York Times editorial writer observed that "There is some sense in performing a "stunt" like this since it has another purpose than that of showing how near to killing himself an aviator can come without doing it." $\mathrm{V}-36$ F.1y's fame spread nationwide, and he was showered with honors. He was appointed as an aviation instructor for the California Squad of the Coast Artiliery Corps, the first such squad organized in the United States. He made plans to act. as a distributor for Curtiss aeroplanes on the west coast. Ely's schedule, however, demanded the completion of exhibition tours for 1911, and stops that year included triumphant return appearances in Oregon.

Ely returned to the state where he began his aviation career as one of the most recognized aviators in the world. It is quite amazing, then, that he remembered his promise to fly again in Medford. In the early days of June $1911 \mathrm{Ely}$ and his entourage of mechanics and reporters arrived in Medford to the astonishment of the local populace. Ely did not have the Werme machine with him but instead carried two excellent Curtiss aeroplanes - - exumples of the best that the factory could produce in 1911. The Medford Mail acknowledged that a stop in its city might seem odd but "Only his failure here before led him to agree to appear here." $\mathrm{V}-37$

A local reporter for the newspaper covered the big show, and his accounts provide some fascinating insights into public reaction to the 
aviator and the aeroplane. He analyzed lccal crowds, and he sought to discover the source of tineir attraction to Ely. In one article he pondered :

Whether it was the thrill that a courageous and conscientious man was soon to defy death itself, or whether it was the almost vulgar trait of every human being to enjoy the sensation of a thrill, or whether it was the personal power of Eugene Ely himself, is too great a question to answer. $v-38$

Although the writer kept one eye on Ely as flight preparations were made, he also was excited by the people's fascination with the event, as can be seen in the following account:

Some uncommon force was working on the assemblage of Medford people and there was not a toot of an automobile horn or a cry or a semblage of festivity in tine tuass of people. There was simply interest, pure human interest in what was about to happen. People went to see the greatest invention of modern times - man's connuest of the air - as exemplified by an aviator whose name is a household word the world over. $\mathrm{v}-39$

Ely checked the aeroplane, tightened a few wires, climbed in the seat, and took off without delay and without signs that he was nervous. The people in Medford, expecting numerous faise staris, were stunned, "too interested to cheer, looking on with breathless suspense." $\mathrm{V}-40$ Ely soared above them for nine minutes and made a dramatic landing. "The descent is made," the reporter wrote,

by a succession of dips and balances, each operation bringing the machine nearer the earth, as though it were coming down a huge aerial stairway. At last it is within a foot oi the ground. It skims along with the grace of a seagul1. until, at length, it lights and comes to a stop. One almost expects to see it fold its wings. $\mathrm{v}-41$

Ely performed three flights that day with flawless success. As he drove away from Medford to catch a train to Salem, Oregon, his manager Norman Devaux reportedly informed Ely that receipts for the exhibition were excellent. Ely, pleased that his record of failure had been 
cleansed, responded, "Oh, bother the receipts." the Medford Mail recalled the failure of 1910; the reporter especially remembered that Ely's manager at that time, a man named Bryce, had warned the local people that Ely would make them eat their words of ridicule. Bryce had said, "Yes, laugh at him. Next year he may be the most famous of them all-yea-more. I predict it." $\mathrm{V}-43$ "He was some prophet," said the reporter, "wasn't he?"1-44

Ely's next stop, Salem, greeted him with similar enthusiasm. The Oregon Statesman urged parents to bring their children to the exhibition for a treat they would long remember. ${ }^{\mathrm{V}-45}$ Ten Salem businessmen each contributed $\$ 100$ to secure Ely's contract. The flights were well advertised; as one ad declared, "It is perhaps redundancy to say that Ely is a leader amorig aviators. His flights have been universally successful and the things he does with the big machines are simply wonderful." $\mathrm{V}-46$ His appearance in Salem was for a short period, but his flights wer again successful. He raced an automobile and a motorcycle, and he surprised everyone by leaving the fairgrounds and venturing to the center of town where he circled the capitol dome of the state legislature. That particular flight lasted only six minutes, but upon landing the crowd yelled its apreciation, and some people swarmed around the aeroplane and pencilled their names on the wing canvas. -47

With his preliminary stops completed, Ely came to Portland as the main attraction at the Rose Festival. He promised Wemme a ride, but the businessman declined, saying that he had no desire to fly. Ely made three flights on June 6th, clrcling downtown Portland and dropplng flour sacks on the business district. A young boy, Harold Rice, remembered 
Ely's exhibition some time later: "My cousin and I went to see it together, paying a good silver dollar each for grandstand seats." $\mathrm{V}-48$ The boys unfortunately went to the exhibition on June 7th. Ely's aeroplane had a broken connecting rod that day preventing further flights. After his first flight Ely landed the aeroplane and announced that the exhibition was completed. Although disturbed by this problem Ely displayed a maturity born from success, when he told reporters that he might return and try again. He no longer felt the great desire to prove himself to crowds and he realized that one failure could not damage his established reputation. But it was in Portland that he confided his constant dread of a fatal crash to Weme whom Ely told that the large amounts of prize money was not worth the risk of death.

Still, Ely had contracts to fulfill, and, although he intimated that 1911 might be his last year for exhibitions, he had an August date in Chicago for the International Aviation Meet. At that extravaganza Ely pocketed $\$ 4,672$ in prize money, a to $\$ a l$ surpassed by few others. $\mathrm{V}-49$ While in his hometown of Davenport, Iowa in early october, the aviator was asked again when he planned to retire; he simply said, "Oh, I'll do like the rest of them . . keep it up until I'm killed."V-50

Ely was killed in an accident at Macon, Georgia on October 19, 1911. It was the next to the last day of his last scheduled exhibition for that year. Lying next to the wreckage from which he had attempted to jump, Ely could only say, "I lost control. I know that I am going to die." $\mathrm{V}-51$ He died a few minutes later, and souvenir hunters removed his collar, cap, and gloves. It was a tragic ending to a brief but meteoric career which featured a 1 ise from obscurity in Portland to a ranking with 
the best aviators. Henry Wemme displayed a somber reaction to the accident, saying that he felt somewhat responsible because he soid the aviator his first aeroplane. Wemme provided a fitting epitaph for Ely when he said:

Bright, determined, and of high character, Ely needed only the opportunity to make a name for himself. . . . When he was seized with a desire to pilot an aeroplane he went about the work with the great determination that presaged success. $\mathrm{V}-52$

Practical aviators like John Burkhari worked behind the scenes and were responsible for improvements in aeroplane technology. Amateur aviators, those who failed to make imprints in the field, were killed or realized when it was time to quit. The daring and skilled avlators, those who brought the aeroplane before the public at great personal risk, immortalized themselves by securing the acquisition of the daring and romantic label. The exhibition aviators met existing standards of performance and set new ones. Eugene Ely had met all of the requirements, and even today his name is mentioned in most aviation history books. $\mathrm{V}-53$ 
NOTES

CHAPTER V

1 The Albany Democrat, Feb. 1910.

2 "Portland Aviator Flies With Ease," The Oregonian, 10 Apr. 1910, p. 7, col. 1 .

3 "Aviator in Peril," The Oregonian, 15 July 1915, p. 13, col. 3; "Pastime Is Flying," The Oregonian, 18 July 1915, sec. 1, p. 9, co1s. 45; "Portland Youth Is Helping Solve the Aeroplane Problem," Oregon Journal, 27 May 1917, sec. 3, p. 6, col. 1; "Local Boys Climb," The Oregonian, 9 Sept. 1917, p. 16, col. 1.

4 Danny Grecco, Letter to Patrick Harris, 28 May 1980, filed with Manuscripts Department of the Oregon Historical Society.

5 "Aviator Will Fly," The Oregonian, 9 Mar. 1913, p. 10, col. 4.

6 "Obituary," The Oregonian, 18 May 1926, p. 20, col. 4.

7 John Burkhart's phorograph albuws, vols. 1-2, Multnomah County Library, Portland, Oregon.

8 Evelyn Santee, "John Burkliart: First Oregon Plane Builder," The Oregonian, 27 Apr. 1947, mag. sec., p. 1, cols. 1-7.

9 The Morning Astoriun carried only advertisements about Manning's intentions such as the following: "Advertisement," Morning Astorian, 17 Juiy 1910 , p. 8, cols. 4-7.

10 "About Astoria," Daily Budget, 16 July 1910, p. 6, col. 3; "The First Aeroplane," Cumtex: The Clatsop County Hiscorical Society Quarterly, I (198I), p. I1.

11 "Hurt Man Awakes," The Oregonian, 12 Aug. 1910, p. 2, cols. 2-3.

12 "Aviator Much Hurt," The Oregonian. 13 Aug. 1910, p. 2, col. 2.

13 "Portland Youths Run Agency for Aeroplane Parts," Oregon Journal, 4 Sept. 1910, sec, 7, p. 6, col. 1,

14 "Gay Week Begins: B1g Show Is On," The Oregorian, 5 Sept. 1910, p. 8 , cols. 1-2. 
15 "Crowds Saw Some of Best-blooded Stock in Nation," Oregon Journal, 11 Sept. 1910, sec. 1, p. 8, col. 1 .

16 "Air Craft Stolen," The Oregonian, 5 Nov. 1910, p. 17, col. 1.

17 Frank Ellis, "Flying in British Columbia, 1910-1914," British Columbia Historical Quarterly, 3 (1939), p. 237.

18

E11is, p. 237.

19 Scamehorn, p. 57.

20 Roscoe Fawcett, "Walsh Flies High Over East Side," The Oregonian, 23 May 1911, p. 9, col. 1.

21 "Two Vaudeville Stars Take Trip to the Skies," The Oregonian, 26 May 1911, p. 14, cols. 2-3.

22 The Oregonian, 26 May, 1911.

23 "Aviator Walsh in New Bi-plane Makes Successful Flights," Yancouver Columbian, 16 June 1911, p. 5, cols. 1-2.

24 Vancouver Columbian, 16 June 1911.

25 "Invention Which Will Make Aviation Safe," Vancouver Columbian, 21 June 1911, p. 1, cols. 4-6.

26

Charles M. Thomas, rev. of Miracle at Ritty Hawk, The Letters of Wilbur and Orville Wright, ed. Fred C. Kelly, Mississippi Valley Historical Review, 38 (1952), 727-728.

27 Combs and Cardin, p. 345.

28 "Ely Is Upset In Wemme Aeroplane," The Oregonian, 14 Apr. 1910, p. 15, col. 1 .

23 "Aviator Kelly Makes Successful Trial Flight," Medford Mail, 2 June 1910, p. 1, col. 5, p. 8, col. 3.

30 "Brains Are First," The Oregonian, 31 Oct. 1910, p. 2, col. 4.

31 "Aviator Picked up Dying," New York Times, 17 July 1910, p. 2, col. 5 .

32 "Throngs Cheer E1y Start," New York Times, 10 Oct. 1910, p. 2, cols. 1-2.

33 "Aeroplane Crippled, Ely Gives up Flight," New York Times, 12 Oct. 1910, p. 2, col. 5 . 
34 "Flies to Warship Then Back Again," The New York Times, 19 Jan. 1911, p. 1, col. 3.

35 New York Times, 19 Jan. 1911.

36 "Aviation with a Purpose," Editorial, New York Times, 20 Jan. 1911, p. 10, col. 4.

37 "Manbird Ely Makes Good on Aviation Field Where He Falled One Year Ago," Medford Mail, 4 June 1911, p. 1, col. 1, p. 6, cols. 1-3.

40 Medford Mail, 4 June 1911.

41 Medford Mail, 4 June 1911.

42 Medford Mail, 4 J.ne 1911.

43 Medford Mail, 4 June 1911.

44 Medford Mail, 4 June 1911.

45 "Noted Aviator Will Fly High," Oregon Statesman, 30 May 1911, p. 1, col. 2 .

46 "Ely Will Start at 2:30 Today," Oregon Statesman, 4 June 1911, p. 1 , cols. 6-7.

47 "State Capitol Dome Circled," Oregon Statesman, 6 June 1911, p. 1, col. 3, p. 7, col. 4 .

48 Harold Rice, "Columoia River Kid," Oregon Historical Quarterly, 74 (1973), p. 316.

49 Scamehorn, p. 85.

50 "Ely Killed; Leaps Free of Aeroplane," New York Times, 20 Oct. 1911, p. 1, cols. 1-2, p. 2, col. 2 .

51 New York Times, 20 oct. 1911.

52 "Ily First Flew in Portland," The Oregonian, 20 oct. 1911, p. 1, col. 7, p. 4, col. 2 .

53 Some of these works include: Morris and Smith, pp. 120-120; Scamehorn, pp. 79, 92; Taylor and Munson, p. 128. 
CHAPTER VI

\section{SILAS CHRISTOFFERSON AND THE TRANSITION ERA}

The zeroplane was not completely practical by 1912 , but an increasing number of citizens believed that it would eventially have purposeful applications. Silas Christofferson began his flying career when exhibitions were common, yet he performed stunts in Oregon and elsewhere that no other aviator had attempted and thus guaranteed himself a share of public attention. Christofferson was a master at simultaneously thrilling the spectators and testing his machine. In that sense he was a transition figure, an aviator better adapted to the great exhibitions, but also comfortable as a test pilot seeking practical applications for the aeroplane.

Christofferson was born near Des Moines, Iowa in 1890 and moved with his parents to California six years later. In 1910 he came to Portland ard worked as a mechanic for the F. A. Bennett Automobile Company. He established a reputation in the Northwest by winning first place in the Rose Festival Road Race in 1910 and, in 1911, by capturing the Pacific Coast Championship for motorboat racing in the twenty-five foot class. VI-1 He developed an interest in flying aeroplanes after witnessing an exhibition by the English aviator, Hubert Latham, in California. With Bennett's financial help in Portland, Christofferson and his brother Harry built a monoplane patterned after Louis Blexiot's In France. However, Cliristofferson had problems obtaining accurate design specifications for the monoplane and his tests, carried out at 
the army barracks in Vancouver, Washington during May and June 1911 were inconclusive. $^{\text {VI-2 }}$ He returned to California, received lessons in a Curtiss aeroplane, and mastered the art. Bennett financed the building of a Curtiss bi-plane, and Christofferson brought it to Vancouver in May 1912 and flew it over the city. The Vancouver Columbian noted his improvement during the year in comparison to his initial tests when "Many thought he wasted his time and some ridiculed him, ..." Christofferson's return performance demonstrated that "these experimentations made him successful."VI-3 The aviator displayed his confidence by carrying passengers including Emma Becker, his future wife, who commented that flying was "going to be a popular thing with women in the next few years. "IV-4

From Mid-May through the first week in June 1912 Christofferson flew three to five times daily in Vancouver. Then, in a surprise announcement, he stated an intention to fly his aeroplane from the roof of the ten story Multnomah Hotel in downtown Portland. Although the image of the daring aviator was common by this time, the idea of a man flying an aeroplane from the roof of a major hotel in the business section of a sizeable city seemed foolhardy. Nevertheless, Christofferson flew his aeroplane across the Columbia River on June 8 th, the first time that had been accomplished, and landed it at the Rose City Country Club where his mechanics disassembled the plane and carted it to the roof of the hotel. Reporters approached Christofferson seeking to ascertain his motivations for the risky venture, and the aviator's response reflected his feelings about public demands. In a quiet moment Christofferson offered: 
This is an age of do it first. Be original; don' $t$ copy. When a feat has once been performed the people tire of it and expect the next performer to give something entirely new. That is the only reason I have decided to make a flight from the top of the Multnomah Hotel Tuesday afternoon. It will be the ffirst
exhibition of its kind in the history of aviation.

Some observers saw no point in dangerous stunts. Adolfe Behrunds, a vaudeville actor and former German aviator, who was in Portland that week, claimed that some aviators had a sense of false courage which led them to carelessness. The Oregon Journal supported this assertion, suggesting that "any aviator who persists in making tricks, turns and glides will forfeit his life eventually." VI-6 Christofferson, however, felt that he knew what he was dolng and had an accurate sense of public demands. The aviator was expected to risk his life and thrill the crowd, and a flight from a tail hotel promised to fill the requirements. Not for one moment did Christofferson betray a lack of confidence in his public statements. As he told one observer:

I am not unaware of the danger attending my proposed flight Tuesday and have been told repeatedly that I would "back down" at the last minute and not deliver the goods. But $I$ have every confidenge in myself and will make the flight prompty at 2 o'clock.

In an age when newspapers and magazines summoned the aviator to search for practical applications for the aeroplane, Christofferson proved that in aviator's romantic appeal had not been lost. Fifty thousand people, the largest crowd to attend an aviation event in Oregon since the appearance of Charles Hamilton, jammed downtown Portland on June $12 \mathrm{ch}$ and watched Christofferson lift successfully from the roof into the air. They broke out into loud cheers as he headed out cver the city and began to cross the Columbia River. The aviator was temporarily 
confused as to his location but realized that he was on tine right path when he spotted the ferry crossing from Portland to Vancouver. The Oregonian granted that "aviation science took another stride toward perfection yesterday afternoon."VI-8 The paper also praised Christofferson for using an aeroplane for practical purposes:

Other aviators have made speedier journeys but it remained for the unlicensed ex-automobile racer to ploneer in trusting his heavier-than-air machine in a start from the midst of the business section of a great city. VI-9

As Christofferson had predicted, his flight made him a famous man. He was asked to fly all over the Northwest and sifted through the requests. The week following his historic flight, Christofferson tested the same aeroplane with pontoon attachments to see if it could land on the water. With the success of this test he ended his close assoctation with Bennett. In mid-June Christofferson arranged to fly an aeroplane owned by two Oregon lumbermen, Brice Wilson and Everett Cox. Bennett countered by signing Walter Edwards, an aviator from Califormia, and, for a short period, a competition raged between the men. They both used the base at Vancouver until Christofferson left to go on his own during August.

Edwards flew unannounced over Portland on August 3rd following an elliptical course around the city to Willamette Heights and crossing Macleay Park. He flew the aeroplane that Christofferson had taken from the hotel as a practice for a scheduled air mail route that Edwards hoped to fly the next week. Bennett believed that Edwards' flight was evidence that the aviator was in the same class as that of Eugene Ely and Lincoln Beachey. When official authorization was received establishing a post-office sub-station at the Rose City Country Club, 
mail delivery was scheduled for August 1lth. Portlanders participated in the frivolous affair by sending letters to the post office addressed to Theodore Roosevelt and President Taft. Although Edwards only planned to carry letters to Vancouver, he hoped to become the first interstate air mail carrier in United States history. The Oregonian cryptically remarked, "Regular service, of course, is not contemplated."VI-10 A sizeable crowd gathered at the Country $\mathrm{Club}$ and, as usual, most remained outside. They passed last minute letters through the fence in an effort to get their messages on the aeroplane. Edwards took his historic opportunity in stride quipping, "No dog wiil truable me. He'd have to be a combination of a Russian stag-hound and a sea-gul1. . ."VI-11 The aviator made three trips back and forth across the river on Saturday and repeated the stunt in difficult winds the next day, August 12 th. Christofferson was not to be spstaged by this newcomer to the region. A week later he flew the Wilson-Cox aeroplane under the spans of the Morrison, Hawthorne, and Burnside bridges before effecting a landing on the Willamette River. He rose into the air seven times on August 18 th and once carried Cox's thirteen year old son with him. He also diverted attention from the oldest pastime to the newest when he flew directly over the Vaughn Street baseball park while a game was in progress. "When the seroplane was sighted . . .," one paper noted, "the game was virtually forgotten while thousands zushed to points of vantage to view the flier."VI-12

With his local reputation secure by September 1912, Christofferson flew at the fairs that offered him the best salaries. When he advertised in newspapers that "If you like thrills, come and see me 
today," people knew that he was not a charlatan. VI-13 His appearance at Coos Bay, Oregon is illustrative of his exhibitions that fall. He signed a contract to perform over the city on 0ctober 26 th and 27 th, a contract that offered residents of Southwest Oregon a chance to see an aeroplane for the first time. The Coos Bay Times sponsored the exhibition and promoted it heavily. Silas's brother Harry visited Coos Bay on October 15th to selezt an aiz field and to give the people information about his brother. He also spoke of his own experiences in the following way:

I learned in a Wright machine with Mr. Gill at my side. We had double sets of controls and I was allowed to operate, but he was at my side and corrected any mistake that $I$ made. We went high up in the air for my training, but in the Curtiss machine, where there is but room for one operator, the learner is generally given a weak-powered machine at first so that he can run along the ground and cannot possibly fly up but a short distance. My brother, in learning on the Curtiss machine, had a high-powered one and he went high up in the air and could not control the machine and it crashed to the ground. He was badly bruised and the machine wrecked and it was a miracle he was not killed.

Thus Harry Christofferson filled in gaps about the brothers' early experiences with the aeroplane. This interview, carried only in the Coos bay Iimes, provided information that Portland's newspapers had not reported. Beginning in mid-October advertisements about the exhibition appeared in the T1mes every day. People in Southwest Oregon were urged to witness man triumph over the air as Christoffersn demonstrated his absolute control of the aeroplana. The Times praised Christefferson for his wlllingness to meet with the people to discuss the aeroplane and its technology. Children were especially asked to come because the exhibition would be "educational as well as interesting."VI-15 Silas Christofferson arrived in Coos Bay October 24th, assembled 
his aeroplane the next day and made six flights on 0ctober 26 th and 27 th. Several local residents paid fifteen dollars for the honor to fly with the aviator and many remained on a waiting list. Young ladies found Christofferson attractive, but the Times admonished them: "Mister Christofferson is in receipt of many letters from girls and others asking permission to ride the air with him. He is unmarried but during his flights he has litt.1 " time for 1ight gossip."VI-16

Christofferson remained in Coos Bay another week to accommodate the overflow crowd and subsequently made an additional thirty flights. Passengers included men such as Vern Gorst, the eventual founder of Pacific Air Transportation Company, and E. W. Steele, an aviator who made an Oregon coastal flight in one of Gorst's aeroplanes in 1913. Gorst was so fascinated by these experiences with the aeroplane that he purchased a four-passenger tractor hydroplane from Glenn L. Martin hoping to carry people across Coos Bay. The aeroplane was not well received by the public, and it was returned to Martin. VI-17

School children were allowed to watch many of Christofferson's flights. The teacher brought them to the show because, "Miss Williams believes in progressive things."VI-18 Christofferson even carried a duck hunter who admitted that "it is difficuit to shoot ducks but it is a rare sport." VI-19 The aviator was best remembered for his efforts to save the crew of a capsized schooner on October 31st. He flew out orer the breakers with reporter Jack Guyton who wrote a detailed piece which appeared in the Coos Bay Times. "The sensation of looking down on Coos Bay bar," wrote Guyton, "when in a dangerous condition for boats, was to say the least, a peculiar one. With the feeling of safety in an airship 
that a novice could scarcely expect, below was seen only the crashing sea."VI-20 Guyton, absorbed by the experience, believed that he understnod how it was that aviators lost a sense of fear once they were in the air. "The excitement and novelty of the situation," he said, "was such that the danger was not so greatly considered."VI-21 Still, the reporter expressed the hope that the "gas engine would not break down at that particular place."VI-22 Christofferson was unable to save the crew, but he had again mixed practicality with drama. It was his master card, and he always played it to the hilt.

This showmanship is no better demonstrated than when he announced his marriage plans to Emma Becker in early November. His honeymooñ included an aeroplane trip which the Oregcn Journal considered as stirringly romantic as the romance penned by Sir walter Scott in his poems. The paper dubbed the aviator "Young Lochinvar", sealing Christofferson's romantic and daring image. VI-23

But his days in Oregon were short because he discovered that his ambitions went beyond those of local investors. Most pecple believed that the aeroplane, at its level of technological development in 1913, could not handle the practical demands of everyday life. Christofferson did promise to instruct Howard Covey, still trying to fly, and other students in early 1913, but he left the state for California before the spring. VI-24 He proved his expertise in that state through numerous enterprises. He operated an aviation school and aeroplane factory in Redwood City and Instructed men such as Roland Amundson, the Arctic explorer, and novice aviators from Mexico and Japan sent by their governments. His success is measured in one way by the fact that one 
source claims he earned $\$ 96,000$ in 1912 and 1913. Christofferson was the first man to fly from San Francisco to San Dlego, the winner of an air race from San Francisco to Bakersfield, and the first aviator to fly over Mt. Whitney. He duplicated the loop the loop performed by Adolfe Pegout, a French aviator, and he completed several deals with foreign governments after receiving only lukewarm response from his own. VI-25 Christofferson constantly warned Americans that foreign governments were far ahead of America in their applications of the aeroplane. Thus, when he returned to Portland for exhibitions in July 1914, the city turned out to greet an aviator whose name was commonly known in aviacion circles. Christofferson received the attention graciously and recalled his friends in Portland "who helped start me in the aviation game."VI-26 One of his major sponsors for tiat trip was Jacob Hill Cook, of the Multnomah Box Company. VI-27 The people who watched him take off from his mooring at Windemuth's Boat House on the Willamette saw that Christofferson remained as daring as ever. He flew under clty bridges, carried motion picture photographer E. Carl Wallin with him, and generally displayed the superior design of the aeroplanes his company manufactured. City Commissioner W. L. Lightner, excited by the idea of motion pictures being made of Portland from the air, exclaimed "Motion pictures. . will be sent all over the world and Portland ought to recelve thousands of dollars of the best kind of advertising from 1t." VI-28 In the spirit of Theodore Hardee and E. Henry Wemme, Lightner recognized that successful aviation exhibitions alded a region's selfconfidence, image, and economic well-being.

Portlanders felt honored to host one of America's latest great 
exhibition aviators and Christofferson, like Ely, was one of their own. Christofferson was a practical aviator, yet he also believed that aviators should take the aeroplane to the public, and he accepted the Idea of the exhibition as the place where it could be tested. His own death came when he crashed in 1916 while testing a difficult aeroplane that had already killed one of his students. It was not a public exhibition; the aviator never flew a dangerous aeroplane in public. As Christofferson lay dying he was asiked by friends what had happened. His answer was that he did not know. V/I-29

That was the thrill, that was tine danger faced by the pioneer aviators. Before technology had made the aercplan a safe machine, the best aviators were the ones who demonstrated the most consistent ccntrol; a control measured in part by the duration of their life. Even the best aviaiurs knew that at any point something could go wrong, and that they could die without knowing why. The initial age of exhibitions came to an end when these individuals no longer had to solve the problems on their own but had government and business support behind them. Exhibitions continued after World War I, but their spirit and purpose had changed. Christofferson was closely connected to this transition era, and Webster A. Jones, writing for The Oregonian in 1931, evaluated the aviator's significance by pointing out that he was more than a stunt pilot. "To understand what he did for aviation," Jones wrote, "his stunts must not be exaggerated. He was primarily an aeronautical engineer; his designs show steady and significant advancement. He was a silent, methodical laborer for aeronautics."VI-30 
NOTES

\section{CHAPTER VI}

1 "Aviator Flies Off Hotel Safely," The Oregonian, 12 June . 2912, p. 1, col. 5, p. 14, cols. 1-3.

2 "Bleriot to Fly Later in Week; Rudder Breaks," Vancouver Columbian, 30 May 1911, p. 1, col. 2; "Aviator Flies 'A Bit' on Parade Ground South of Barracks," Vancouver Columbian, 13 June 1911, p. 5, col. 2.

3 "Christofferson Salls Over City in Bi-plane," Vancouver Columbian, 20 May 1912, p. 1, cols. 5-6.

4 "First Birdwoman Salls Over Beautiful Vancouver," Vancouver Columbian, 23 May 1912, p. 1, ccls. 4-6.

5 "Flight from Roof Beset by Danger," The Oregonian, 10 June 1912, p. $16, \operatorname{col} .4$.

6 "Aviation Given up for Vaudeville," Oregon Journal, 3 June 1912, p. 2, col. 2 .

7

The Oregonian, 10 June 1912.

8

The Oregonian, 12 June 1912.

9 The Oregontan, 12 June 1912.

10 "Aviators Promise Meet of Thrills," The Oregonian, 8 Aug. 1912, p. 10, col. 1 .

11 "1500 Mail Pleces Go by Air Route," The Oregonian, 11 Aug. 1912, p. 16, cols. $1-\bar{z}$.

12

"Alrman Performs Thrilling Feats," Oregon Jourual, 19 Aug. 1912, p. 7, cols. 3-4.

13 "Alrman to Perform Thrilling Feats," Oregon Journal, 25 Aug. 1912, sec. 4, p. 3, cols. 1-2.

14 "Aviator Tells Experiences," Cous Bay Times, 16 Oct. 1912, p. 2, cols. 2-3.

15 "Chrlstofferson Gives Three Flights Here Tomorrow," Coos Bay Times, 29 Oct. 1912, p. 1, cols. 1-2. 
16"22 Flights Made by Christofferson in Two Days," Coos Bay Times, 31 0ct. 1912, p. 1, cols. 1-2.

17

Bonney, p. 139.

18

Coos Bay Times, 31 oct 1912.

19

Coos Bay Times, 31 Oct. 1912.

20 "Goes to Wreck in Hydroplane," Coos Bay Times, 1 Nov. 1912, p. 1, col. 3, p. 6, col. 3 .

21

Coos Bay Times, 1 Nov. 1912.

22

Coos Bay Times, 1 Nov. 1912.

23 "Bridal Tour to be Taken in Aeroplane; Air Pilot Outromances Young Lochinvar," Oregon Journal, 19 Nov. 1912, p. 1, cols. 4-6, p. 17, col. 5 .

24 "A School to Open," The Oregonian, 17 Nov. 1912, p. 17, col. 1.

25 Sidney Jenkins, "Feats of Portland's First Airman Recalled," The Oregonian, 30 Nov. 1930, sec, 2, p. 1, col. 1 .

$20^{\circ}$ "Freak Flying boat Sets Sail Tonight," The Oregonian, 25 July Isi4, p. 10, col. 5 .

27 "Aviator Gives Fine Exhibition of Flying Along Waterfront," Oregon Journal, 26 July 1914, p. , col. 3.

28 The Oregonian, 30 Nov. 1930.

29 "Portland Airman Killed in Flight," The Oregonian, 1 Nov. 1916, p. j, coí. i.

30 Webster A. Jones, "Airport to Honor Memory of Flyer," The Oregonian, 24 May 1931, sec. 1, p. 7, cols. 1-2. 


\section{CHAPTER VII}

\section{CONCLUSION: THE END OF THE EXHIBITIONS}

It is, in a sense, incorrect to state that exhibitions ended after World War I. They still occur. The nature and purpose of the exhibttion changed, however, after 1912, as did percepifons about the aviator's Image. The earliest exhibitions were showcases ror chilis and thrills, the arena where the Individual aviator struggled one on one with the natural elements. Pioneer aviators made a living at these spectacles in an era that presented few other alternatives for other methods of application. Between 1910 and 1915 speculations were constantly heard that a practical aeroplane was right around the corner, but these practical aeroplanes were already being tested at the exhibitions. This final chapter studics the factors that led to a greater deemphasis on the significance of the exhibition and, in particular, how this deemphasis affected the careers of early Oregon aviators.

One factor that led to the end of the exhibition era was the death of many aviators. The death toll was alarmingly high and dangerous exhibitions contributed to this fatality rate. Public expectations were extreme, and aviators of ten flew in poor weather conditions or with unsafe aeroplanes because of audience demands. In addition, the technology was so primitive, and the stresses placed on the fragile aeroplanes by dips and spirals cannot be overlooked. It was dangerous to fly an aeroplane in 1910. 
Newspapers and magazines urged government and business officials to take an interest in aeroplane safety, and, although it was not until World War I that such an interest bore fruit, better technological designs signalled an end to some of the attraction that people had for an exhibition. "The appearance of improved machines," said one author, "made performances once unique and marvelous now ordinary. . . ."VII-1

World War I demonstrated that the aeroplane had potential as a war machine, and localities, heartened by this practical application, encouraged with greater farvor the construction of aeroplanes and airports for commercial purposes.

The aviator's image changed as the nature and purpose of the exhibition changed. Aviators who survived the exhibition rigors and continued to fly at them were still considered iaring but also foolish. The development of modern technology had made stunts anachronistic. The daring, romantic aviator, willing to risk life and limb for the sake of pure entertainment, was a liability to a company seeking to develop a pub1ic image ô safety. Exhibitions attracted crowds because they were exciting, and the avjators made them so. But aviators such as Lincoln Beachey and Silas Christofferson rarely believed they were flying just to thrill a crüd. They consciously realized, more than the spectators ever could, that exhibitions tested aeroplane technology. The death of the aviators hindered public confidence in its eventual application and led to speculation about the aeroplane's safety. Ironically, the monotony of success mixed with the horror of the accidents, $z$ combination that led to lessened public interest in the exhibition. Charles Willard, an aviator for the Curtiss Exhibition Team, had "read the sign of the 
times," and left the circuit in 1912. The luge crowds, so common at exhibitions in 1910 and 1911, had diminished because "once people paid to see an aeroplane $f l y$, and their curiosity had been satisfied, few would return again and again."VII-2 This certafiniy was the case in Oregon. Attendance at aviation meets seldom approached the figures attracted by Charles Hamilton.

Between 1911 and 1915 Oregon's newspapers and magazines paid less attention to the exhibitions and more to the practical development of the aeroplane. Some observers cheered the passing of the exhlbition era, while others wondered how the deaths of aviators had contributed tc aviation's progress. One Oregon Journal writer concluded at the end of 1911 that repetitious stunts only proved that aviation had passed from "marvel to monotony."VIII-3 Recognizing Thomas Edison's warning that aeroplanes must be safe if the public would ever want to fly, the same writer commented: "Aviation entered a new phase in 1911. The day of spectacular glides and spirals is passing. A class of scientific men - engineers and sailors - - is developirg long distance flying along safe and sane lines."VII-4 This belief that long distance flying was more practical than the exhibition centered around a common feeling that a flight from New York to London was, in the long run, more practical than spirals over Philadelphia. Aviators who risked their lives in these longer flights were still honored. They were not considered foolish because they were studying practical applfcations.

In 1914, The Or 2 gontan ran a series of editorials which analyzed the technological improvements of the aeroplane as well as the changes coming to the world as a result. A projected flight across the Atlantic 
Ocean was the spur for this discussion. Although only "maniacs" would have attempted such a flight a few years before, The Oregonian predicted that I. D. Porte and Rodman Wanamaker would "go through with it unscathed."VII-5 Porte was described as a "robust man who has seen many perils by land and sea without losing his appetite for new adventures." Wanamaker possessed a "daredevil spirit." While the flight was very dangerous, the paper reported that with "two heroes of this quality the flight stands a fair chance of being achieved."VII-6

The aviators were honored because the flight attempt was practical. Travel across the Atlantic was "one of the certainties of the near future,"VII-7 Later in July the paper urged Oregonians to recognize that man "is to become a flying creature."VII-8 It was hard for people of that time to understand the awesome changes that technological improvements had brought to the world. "The wnrld a hundred years hence," pondered a writer, "doubtless would be quite as marvelous a place to us of today as the present time would be to one of our progenitors of $a$ hundred years ago."VII-9 Still, there were certain technoiogical changes that contemporary observers could not ancicipate. Although Heinrich Oelrich had flown an aeroplane to 25,000 feet in 1914, The Oregonian asserted that "It is evident that there are heights above which our physical weakness will not permit us to ascenc."VII-10 Americans realized that there were certain practical applications for the aeroplane. Exhibition flying ceased to be one of these by 1912. But, oddly enough, Lincoln Beachey attracted huge crowds even to his death in an accident in 1915. The thrill of the exhibition retained a certain pull, and still does, long after it was derided as impractical. 
Practical applications for the aeroplane came slowly to Oregon. From the vantage point of 1920 , one writer noted that aviation in Oregon went into a lull after Christofferson left the state, a lull which lasted unt11 1919. In fact, peace time applications were debated well into the 1920's. VII-11 The Oregon, Washington and Idaho Airplane Company, formed after World War I, collapsed in the early twenties. Danny Greco, a mechanic and stuntman for the company, simply felt that people were not "air-minded."VII-12 The Portland City Counctl banned airplane flights over the city as late as 1921, and attempts to develop alrports and air mail service were not very successful unt11 1926. VII-13 Thus, sixteen years passed between the rime of Hamilton's exhibitions in Oregon and the start of the afr mall route along the Pactfic coast. The aviators who flew in Oregon during the exhibition era helped people accustom themselves to the sight of an aeroplane. Most of these aviators passed from the aviation scene with the exhibition, and their personal contributions have been largely obscured.

Lincoln Beachey lived through the transition period between the airship and the aeroplane. He also lived through the trañistioñ between the exhibition era and the commercial era. He adjusted well to changing publte interests. When he foined the Curtiss Exhibition Team In 1911 he soon became the best stunt pllot of his generation. He set the standard by which exhibition avlators could measure their own performance. He flew over Niagara Falls, landed on the front lawn of the United States Capitol, and performed loops and spirals that left aud1ences gasping long after they ceased paying attention to other aviators. While other fallures "emphasized shortcomings and the need for 
technological improvements," Beachey's continued success was testimony to the apparent fact that at least one man could conquer technology and nature. VII-14 Yet, in 1913, Beachey quit aviation, claiming responsibility for the deaths of aviators such as Eugene Ely and Charles Walsh. He believed that if other aviators had not pushed themselves to duplicate his amazing stunts, they would be living. At that time Beachey revealed a contempt for the crowds that first appeared at Portland in 1905; a contempt that was mistaken for modesty. "I am convinced," he said, "that the only thing that draws crowds to see me is the morbid desire to see me die."VII-15

Beachey was probably correct. Audiences wondered how long he could defy the odds; odds that destroyed his companions one by one. The aviator returned to aviation in 1914 saying that he could not ignore his chosen lifestyle. His return was marked by stops in 126 cities before millions of people. People were willing to pay money to see Beachey. He was the "embodiment of the symbolic aviator, fashioned with such precision and consisiencey." VII-16 when the Panama Paciff.c Exposition was held at San Francisco in 1915, Beachey was the star attraction. While testing a new monoplane on March 14 th he fell to his death in San Francisco Bay hefore thousands of people. The Oregonian criticized Beachey's death at an exhibition because "spectacular evolutions..." did not "contribute anything of value to aviation progress." VII-17 The exinibition that Beachey specialized in was viewed only as "a risk of life to thrill a multitude." The aviator's daring and skill were accepted. When it was dangerous to $f l y$, "Beachey was one of the courageous few who undertook to fly." "That was constructive work," the paper asserted, "but the same 
cannot be sald of air sommersaults or hair-raising dives from high altitudes."VII-18

In an editorial published in The Oregonian the writer concluded that Beachey, "knew the requirements of safety in the air but he did not obey them."VII-19 The New York Times har a less critical appraisal. Howard Huntington, of the Aero Club of America, summarized Beachey's contributions in an interview with the Times:

Beachey died as most of his brothers of the first generation of airmen have died. It is fitting that we close the era of flying of which Eeachey was a part. I mean the era of flying fothrills for a crowd for strictly an exhibition reputation. We know enough now not to go aloft with wings carrying only one set of stay-wires for the daredevil work which won Eeachey his worldwide fame. VII-2.0

The same questions were asked about the other aviators. Eugene Ely, inspired by Beachey and Hamilton, began his aviation career Ain $^{-}$ Oregon. He did not have a spectacular beginning in the state, but financial support and personal determination kept him flying, and he rose to the top of the field. When he returned to Oregon he was greeted with tremendous adulation. His own death, however, in 1911, intensified a growing sense of public frustration that many people experienced when they pondered the risks of flying. Observers asked themselves why their daring heroes vere being killed, and most slowly concludei that courageous character could not prevent an accident in an unsafe machine. The Mannings' story provided evidence that the public would not accept confident proclamations without successful flights. Although the Mannings had adequate financial support, their failures led to speculation by some observers in Oregon that successful aviators possessed certain inborn characteristics which were manifested in their personalities but, most of all, in their flying skill. The character without the 
success was not admired. Finally, when H. W. Manning hired Charles Walsh to pilot his aeroplane, the people in Oregon saw the difference between the successful and unsuccessful avlator. Walsh was an excellent aviator and, like so many others, he drove himself to be the best. While attempting to duplicate Beachey's stunts in 1912, Walsh was killed. He had been the recipient of Oregon's attention in 1911 and gained a measure of his fame because of his appearances in this state.

When Charles Hamilton came to Oregon in 1910, less than two months after the first international aviation meet held in the United States, his reception proved that Oregontans were proud that E. Henry Wemme had suggested such an exhibition to them. Hamilton had wonderful success in Portland although he was nearly killed at Seattle the following week. The heroic images that Oregon's newspapers built around Hamilton were similar to those seen two months later in the New York Times when that paper honored Hamilton by devoting ten pages of an issue to aescriptions of his flight from New York City to Philadelphia. VII-21 Hamilton died of pneumonia in 1914, as a young man, but not as a victim of a crash. His remark that "We shall all be killed if we stay in this business" was true for many aviators but not for him. VII-22

Silas Christofferson was perhaps the most extraordinary aviator that Oregonians saw during the exhibition era. While Beachey performed comparable stunts, Oregonfans never saw hir fly an aeroplane. The two top men were much alike. They understood, beiter than the general public, the connection between exhibition flying and the development of technology. They did not appreciate the hero worship but realized that it was part of being successful. The two men kept flying until they 
were killed, although they outlasted most of their contemporaries in the aviation game. Christofferson remains an aviation legend in Oregon. In 1930 Sidney Jenkins, writing for The Oregonian, recalled that he and his friends had seen Christofferson in flight and wondered, "Holy Mackerel, where will be be if that thing-a-ma-jig falls to pieces?" Jenkins pratsed Christofferson as one of the first to recognize that "so-called stunts" were essential to the growth of aviation technology. VII-23

Oregonians were privileged to see several excellent aeronauts and aviators between 1905 and 1915. None of these heroes had serious accidents while performing in the state. This fact is important when Oregon's high expectations of aviators are evaluated. The newspapers and Dagazines in this state built a portion of the image of the aeronaut and the aviator. Oregon's newspapers and their coverage was representative of a national pattern and had little patience with faiiure. This could be related to the fact that most exhibitions in this state were overwhelmingly successful. The deaths of many aviators in other parts of the country led Oregon's newspapers to be more critical of the exhibition. Nevertheless, publications in Oregon contributed to the development of the image: the image of the daring and responsible aeronaut first and the aviator later. 
NOTES

CHAPTER VII

1 Scamehorn, p. 75 .

2 Martin Cole, The:Lr Eyes on the Skies, (Glendale: Aviation Bork Company, 1979), p. 42 .

3 "The Record of 1911," Editorial, Oregon Journa., 31 Dec. 1911, sec. 2, p. 4, col. 4 .

4 Oregon Journal, 31 Dec. 1911.

5 The Oregonian, 6 July 1914, p. 65, col. 4. 8, $\operatorname{col} .3$.

6 "Flying to Europe," Editorial, The Oregonian, 8 July 1914, p.

7 The Oregonian, 8 July 1914.

8 "Annihilating Space," Editorial. The Oregonian, 12 July 1914, sec. 3, p. 6, $\operatorname{col} .4$.

9 The Oregontan, 12 July 1914.

10 "High F1ying," Editorial, The Oregontan, 22 July 1914, p. 8, col. 1 .

11 "Through the Birdman's Eyes," Oregon Journal, 15 Aug. 1920, mag. sec., p. 3, cols. 1-7.

12 Danny Greco, Letter to Patrick Harris, 28 May 1980.

13 "Flying to be Regulated," The Oregonian, 3 June 1921, p. 6, co1. 3; "Air Mail Starts Over Coast ine," The Oregonian, 15 Sep̧t.

1926, p. 1, col. 7, p. 2, col. 2 .

14 scamehorn, p. 92.

15 "Beachey Cise Qu1t Flying," New York Times, 15 Mar. 1915, p. 5, cols. 2-5.

16 C. D. B. Bryan, The National Air and Space Museum, 2nd prinifing, (New York: Harry No Ahrams = 1980), p. 181 . 
17 "Courage Misapplied," Editorial, The Oregonian, 17 Mar. 1915, p. 8, col. 3 .

18 The Oregonian, 17 Mar. 1915.

19 The Oregonian, 17 Mar. 1915.

20 "End to Daredevil Flying," New York Times, 15 Mar. 1915, p. 5, cols. 5-6.

21 "Hamilton Flies for the Times to Philadelphia and Back in a Day," New York Times, 14 June 1910, story p. 1, related stories, pp. 110.

22 Bryan, F. 181.

23 The Oregonian, 30 Nov. 1930. 
SOURCES CONSULTED

SECONDARY SOURCES

BOOKS

Bonney, Walter T. The Heritage of Kitty Hawk. New York. W. W. Norton, 1962.

Bonney's chapters about Samuel Langley, Glenn Curtiss, and Glen Martin are particularly interesting.

Bryan, C. D. B. The National Air and Space Museum. 2nd printing. New York: Harry N. Abrams, 1980.

This work coniains important archival photographs and information about Lincoln Beachey's later career.

Cole, Martin Their Eyes on the Skies. Glendale: Aviation Book Company, 1979.

Cole's chapter on Charles Willard, a member of Curtiss' exhibition team, is chatty but one of very few about aviation figures other than Orville and Wilbur Wright, and Glenn Curtiss.

Combs, Harry, and Martin Cardin Kill Devil Hill: Discovering the Secret of the Wright Brothers. Boston: Houghton Mifflin, 1979.

A recent work that utilizes just released primary material related to the Wrights.

Crouch, Tom D. A Dream of Wings: Americans and the Airplane, 18751905. New York: W. W. Norton, 1981.

- . an excellent work detailing the caree:s of Octave Chanute, Samuel Langley and Orville and Wilbur Wright. The title is a bit deceptive. While crouch does analyze the scientific communities' role in American acceptance of the alrplane, he pays little attention to the American cultural reactions.

Dwiggins, Don. The Air Devils: The Story of Balloonists, Barnstormers and Stunt Pilots. New York: J. B. Lippincott, 1960.

Dwiggins writes about specific exhibition pilots. His chapter on Lincoln Beachey emphasizes Beachey's attachment to the exhibition.

Gibbs-Smith, Charles H. Aviation: An Historical Survey from Its Origins to the End of World War II. London: Her Magesty's Stationery office, 1970 . 
Gibbs-inith's account of the Parisian reception to a successful Wilbur Wright in 1908 indicates that enthusiasm for aviators was a world-wide phenomena.

Gordon, Arthur American Heritage H1story of Flight. n.p.: American Heritage Publishing, 1962 .

Gordon, working with numerous editors and researchers, studies not only technological improvement but the motivations of the aviators as weil.

Grahame-White, Claude Flying: An Epitome and a Forecast. London: Chat to and Windus, 1930.

Few aviators sat down and wrote about their personal experiences. Grahame-White's book is important in that respect, but it is not well written.

Harper, Harry The Evolution of the Flying Machine: Balloon, Airship, and Airplane. Philadelphia: David McKay, 1930.

Kasson, John F. Civilizing the Machine: Techrology and Republican Values in America, 1776-1900. New York: Grossman, 1976.

Kasson's fine chapter about the Lowell Mill is one instance in which he asserts that Americans have welcomed technolog; but feared change if it was going to interfere with republican values. Throughout his book Kasson notes how Americans adapted their old ideas to the changes. In a sense, the creation of the aviator's imege is one more form of adaptation.

May, Henry F. The End of American Innocence: A Study of the First Years of Our Ttme, 191.2-1917. Chicago: Quadrangle Books, 1959; rpt. New York: Charles A. Knoph = 1954.

May's thesis relates to American conservatives who resisted change. He briefly notes that the airplane was a source of consternation.

Morris, Lloyd, and Kendall Smith Celling Unlimited: The Story of American Aviation from Kitty Hawk to Supersonics. New York: MacMillan, 1953.

These authors study the exhibitions and the drama and excitement produced by them. It is a good book because of the emphasis on cultural reactions but researchers will not be able to icentify source material from it.

Ostrander, Gilman American Civilization in the First Machine Age, 1890-194j. New York: Harper and Row. 1970.

0strander makes several excellent points. He analyzes American ideological resistance to new 1deas. He concl.udes that the age of the machine became incr'asingly an age when younger people had all of the answers. The airplane can easily be understood as a 
machine that young Americans felt symbolized their unlimited horizons if people could gain control over it. Ostrander's comments on Lindberg are full of insight.

Reed, Henry Official History of the Lewis and Clark Centennial Exposition, [Portland]: n.p., 1908 .

Reed firmly believed that Portlanders witnessed historic airship flights in 1905. As the secretary of the exposition he recalled events that he witnessed first hand.

Scamehorn, Howard Lee Balloons to Jets. Chicage: H. Regnery, 1957. Scamehorn details aviation history in Illinois. It is interesting that his history of events in a state focuses as much on the exhibition as mine. It is true, that as more aviation histories are recorded, the exhibition will be on inportant focus for most of them.

Stiüur, Clara Sky Storming Yankee: The Life of Glenn Curtiss. New York: Stackpole Sons, 1937.

Mr. Curtiss has never been studied very well. Clara Studor's work is blographical and gives no credit to sources.

Sullivan, Kark The War Begins. Vol IV of Our Times, 1900-1925. New York: Seribner's Sons: 1932; rpt. 1972.

As a fournalist, Sulivan's comments abutit the airplane are similar to newspaper accounts of the era.

Taylor, John w. R., and Kenneth Munson History of Aviation. London: New Eng1ish Library, 1972.

Villard, Henry Sena $=0$ Contact: The Story of the Early Birds. New York: Bonariza, $1 \overline{948 .}$

MAGAZINES AND JOURNALS

Corn, Joseph J. "Women Pilots and the Selling of Aviation," American Quarterly, 31 (1979), 556-571.

The problems that women had becoming established aviators in light of the aviator's superman image are examined by Corn.

E11is, Frank "Flying in British Columbia, 1910-1914," British Columbia Historical Quarterly, 3 (1939), 227-261.

This article fills in critical gaps about exhibitions performed by Charles Hamilton and the Mannings after leaving Oregon.

Kurutz, Gary F. "'Navigating the Upper Strata' and the Quest for Dirigibility," California History: The Magazine of the California 
Historlcal Society, $58(79-80), 334-347$.

Kurutz provides fascinating background information on Thomas Baldwin.

- "The First Aeroplane," Cumtex: The Clatsop County Historical Soclety Quarter1y, 1 (1981), 11 .

Thomas, Charles M. Rev. of Miricle at Ritty Hawk, ed. Fred C. Kelly, Mississippi Valley Historical Review, 38 (1952), 727-728.

Ward, John Williaw "The Meaning of Lindberg's Flight," American Quarterly, 10 (1958), 3-16.

Ward's account is one of very few attempts to relate the public response to Lindberg with American ideals such as self-reliance, progress, and the pioneer drive.

PRIMARY SOURCES

BOOKS

Kelly, Fred C., Ed. Miracle at Kitty Hawk: The Letters of Wilbur and Orville Wright. New York: Straus and Young, 1951.

Kelly had early access to primary materials. Researchers who want more recent interpretation should consult Crouch, Combs and Cardin.

MAGAZINES AND JOURNALS

"A Review of the World," Current Literature, Oct. 1909, 364-378. - . a good summary of world reaction to the Rheims exhibition.

"Airships Coming," Lewis and Clark Journal, 3, No. 3 (1905), 5. This is the first official announcement by Portland officials that Thomas Baldwin was coming to the exposition.

"Airships in Successful Flights at Exposition," Lewis and Clark Journal, 4, No. 2 (1905), 12-i3.

- . a fine description of Baldwin's airship Angelus as well as Tomlinson's Gelatin.

"Auto Honks," The Spectator, 8 Jan. 1910, 12-13.

This article is the first indication that I have found that Portland businessmen were attracted to Henry Wemme's interest in aeroplanes. 
"Auto Honks," The Spectator, 23 Jan. 1910, 15.

Baldwin, Thomas Scott. "What the Airship Flighis Have Shown," Lewis and Clark Journal, 4, No. 5 (1905), 4-5.

Baldwin's assertion that Portland's flights were very important is evidence that a professional participant rather than exposition spokesmen, saw the airship flights as contributions to aviation.

Glaudy, C. H. "Our Aeronautical Organization," Scientific American, 13 Nov. 1909,350 .

This article demonstrates that a major contemporary magazine wa:s reporting not only scientific advances in aviation but also observations about the aviator's character.

"Dawn of the Age of Flying," Current Literature, July 1908, p. 9.

"Good Shows Cominys," Lewis and Clark Journal, 2, No. 3 (1904), 9. It is very interesting to note that mafor figures in expositions travelled from city to city. This article reveals that John Wakefield worked in Omaha and St. Louis before becoming director of concessions at Portland.

Hero-Dunne, Rhoda "The Aeronauts," Current Literature, Oct. 1909, 455. This poem is representative of many in the era. Several poets believed that aviators had the ability to transform human behavior simpiy by their act of flying.

McClay, Pauline Oelo "My Trip to the Fair," Oregon Historical Quarterly, 80 (1979), 51-66.

While this account is chatiy it does represent the personal reactions of one person to Beachey's airship.

Perkins-Gilman, Chariotte "When We F?y: How the Accomplishment of Aerial Navigation Will Make Necessary a Revision of Human Laws and Customs," Harpers Weekly, 9 Nov. 1907, 1650-1664.

This article represents a feminist's hope that people would recognize the need to improve behavior because the airplane made it more 1tkely that human beings had greater destructive potential.

Post, Augustus "Aero Club of America Founded in . . 1905," Fly, Nov. 1908,10 .

Rice, Harold "Columbla River Kid," Oregon Historical Quarterly, 74 (1973), 293-332.

"Salutatory," Lewis and Clark Journal, 1, No. 1 (1904), 10.

This entire issue is important reading if a researcher wants to understand the mentality behind the great American expositions. 
"The Flying Machine Flies," The Spectator, 12 Mar 1910, 4.

This article expresses the great bitterness that Portland businessmen felt when most observers at Hamilton's air show chose to stand outside the gates and not pay admission.

"When We Can Fly," Living Age, 22 Feb. 1908, 499-502.

"Who, Why, When and Where," Fly, Dec. 1908, 15.

This short piece proves that Join Durkinart's inftial flights on the east coast were significant enough to be covered by a national publication.

"Who, Why, Wher: and Where," Fly, Jan. 1909, 12.

Wright, Wilbur "Flying - - As a Sport - - Its Possibilities," Scientific American, 29 Feb. 1908, 139.

Wilbur Wright was very interested in cultural reactions to the aeroplane. This contemporary report covers this aspect of his relationship to aviation better than modern sources.

NEWSPAPERS

ARTICLES WITH AUTHORS

Beachey, Lincoln "How It Feels to Sail the Sky," Oregon Journal, 17 Sept. 1905, sec 3, p. 3, cols. 1-5.

Fawcett, Roscoe "Walsh Flies High Over East Side," The Oregonian, 23 May 1911, p. 9, col. 1.

Jerkins, Sidney "Feats of Portland's First Airman Recalled," The Oregonian, 30 Nov. 1930, sec. 2, p. 1, col. 1 .

Jones, Webster A. "Airport to Honor Memory of Flyer," The Oregonian, 24 May 1931, sec. 1, p. 7, cols. 1-2.

Keller, George "Hamilton Thrills Crowds by Flights," The Oregonian, 6 Mar. 1910, p. 1, col. 7, D. 8, cols. 1-3.

Santee, Evelyn "John Burkhart: First Oregon Plane Builder," The Oregoniañ, 27 Apr. 1947, mag. sec., p. 1, cols. 1-7.

Santos-Dumont, Alberto "What I Will Do," Oregon Journal, 23 July 1905, sec. 3 , p. 39, cols. 1-3. 
NEWSPAPERS

Albany Democrat, 1910. Oregon Historical Society, Portland, Oregon.

Astoria Dally Budget, 1910. Oregon Historical Society, Portland, Oregon.

Coos Bay Times, 1912. Oregon Historical Society, Portland, Oregon.

This newspaper covered the appearances of Silas

Christofferson in Coos Bay, Oregon during late October 1912. Some of the articles gave personal information about the aviator that I have not founa in other sources.

Evering Telegram, 1910. Oregon Historical Society, Portland, Oregon.

On the whole, this Portland newspaper gives sketchy coverage of aviation events. However, the articles about Charles Hamilton are very entertaining.

Medford Mail, 1910, 1911. Oregon Historical Society, Portland, Oregon. In my opinion, this paper provided the best coverage of local exhibitions.

Morning Astorian, 1910. Oregon Historical Society, Portland, Oregon. Citizens of Astoria recelved excellent coverage related to national and international aviation events because of this paper.

New York Times, 1904-06, 1910-11, 1915. Portland State University Portland, Oregon.

This newspaper often seemed to report aviation stories with tongue-in-cheek. Nevertheless, patterns of regional coverage can be compared with that in the Times and similarity in reporting style is present.

Oregon Journal, 1905, 1910-12, 1916, 1920. Multnomah County Library; Oregon Historical Soclety, Portland, Oregon.

Oregon Statesman, 1911, Oregon Historical Society, Protland, Oregon.

The Oregonian, 1905, 1908-1916, 1921, 1926, 1930-1, 1947. Portland

State Ũniversity; julultnomah County Library, Portland, Oregon. This newspaper has the best index of aviation history but it is still not very good. There is no index at all for 1911, 1912 and 1913, very critical years of this study. The reporting, however, was of ten detailed and filled with a sense of excitement. The Oregonian proved to be the best local source for aviation news.

Vancouver Columbian, 1911, 1912. Oregon Historical Society, Fortland Oregon. 
MANUSCRIPTS

Burkhart, John. Photograph albums, vois. 1-2, Multnomah County Library, Portland, Oregon

These rare and personal phot graphs show Burkhart's different

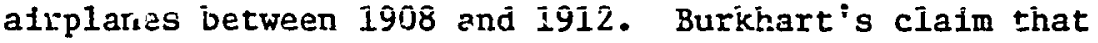
he knew and photographed Glenn Curtiss, Orville and Wilbur Wright, and Thomas Baldwin is substantiated as a result.

Greco, Danny, Letter to Patrick Harris, 28 May 1980, Oregori Historical Society, Portland, Oregon.

Mx. Cxeco was an observer at the Lewis and Clark Exposition and a friend of most Oregon pinneer aviators. ile is the only remaining pioneer of the exhibition era, and his eight page letter details his accounts of those days.

Lewis and Clark Centennial Exposition Papers. Mss. 1609, Orezon Historical Society, Portland, Oregon.

These docuwents reveal the behind-the-scenes negotiations that made possible the appearance of Baldwin's airship at the exposition. 